\title{
Política partidária e meio ambiente: a adesão dos partidos políticos brasileiros à agenda verde
}

Antonio Teixeira de Barros

\section{Introdução}

O objetivo deste artigo é analisar como os partidos políticos incluem temas da agenda ambiental em seus programas partidários na atualidade. O propósito é mapear como se dá a incorporação das pautas ecológicas nos websites das legendas e como as temáticas ambientais são articuladas nos programas partidários e que aspectos são enfatizados, além das propostas políticas apresentadas, do perfil de governança defendido pelos partidos e pela noção de sustentabilidade que orienta o discurso partidário. $O$ artigo pretende contribuir para a compreensão do processo político que levou a agenda ambiental a ser apropriada e incorporada pelos programas e bandeiras dos partidos políticos, considerando que as diversas legendas representam a pluralidade ideológica da política (Peirano, 2011). Portanto, oferecem, no âmbito do sistema de representação democrático liberal, as possibilidades de adesão política aos eleitores. As diferentes agremiações correspondem às distintas visões e divisões do mercado político e dos movimentos ecológicos.

O período eleitoral é relevante por se tratar do momento em que, ao lançarem suas candidaturas, os partidos usam variadas estratégias para reforçar seu papel na mediação política e seu poder de palavra e de influência na esfera pública. Ficam em evidência, portanto, as estratégias de publicidade política, entendidas como uma forma de propaganda das legendas a fim de consolidar seu poder. Essa provavelmente é uma das razões que explicam a ampla adesão dos partidos à defesa de argumentos e práticas relacionados à agenda socioambiental. Durante a campanha eleitoral os candidatos tornam-se porta-vozes do discurso das legendas.

É oportuno ressaltar que a agenda ecológica adquiriu projeção com a intensa midiatização do tema, especialmente a partir da Cúpula da Terra (Rio-92), resultando em uma crescente visibilidade midiática (Barros, 2013). Da mesma forma, a política tornouse um fenômeno igualmente midiatizado, o que inclui a atuação dos partidos. Além dos media convencionais, Urbinati (2013a, 2013b) destaca o papel da internet nesse processo de midiatização, tornando-se um "suporte sem precedentes para a democracia de audiência" (2013a, p. 10).

Várias análises enfatizam a crise da mediação política nas sociedades contemporâneas, representada, em boa parte, pela crise dos próprios partidos, o que resultou na chamada desideologização partidária (Panebianco, 1990). Outros autores 
ressaltam a baixa institucionalização partidária no Brasil, a fraca identificação com o eleitorado (Carreirão e Kinzo, 2004; Veiga, 2007) e uma tendência geral na diminuição da importância dos partidos políticos (Mainwaring, 2001; Maia, 2006; Baquero, 2000; Manin, 1995). As pesquisas realizadas nas últimas décadas no Brasil revelam um declínio na confiança do público em relação aos partidos (Moisés, 2005; Meneguello, 2000) e também no nível de filiação ou estabilidade nas preferências partidárias (Pereira, 2014). Segundo Manin (2013), os partidos deixaram de ser sujeitos políticos com identidades definidas e passaram a ser apenas instrumentos dos eleitores, empregados a cada eleição, dependendo das circunstâncias políticas.

Por outro lado, pensadores políticos ressaltam que, apesar das redefinições frequentes, frutos das crises e metamorfoses da democracia (Urbinati, 2013a), os partidos políticos ainda conservam algumas características e funções que lhes são peculiares na esfera de pertinência da mediação política e das configurações associativas (Weber, 1999). Segundo Manin, apesar de perderem força em várias áreas, os partidos continuam dominando a política parlamentar e as campanhas eleitorais em todos os países (Manin, 2013). Mesmo com a pluralidade de funções, interesses e desenhos institucionais, há um elemento que define por essência um partido político, ou seja, seu caráter de associação (Weber, 1999; Oppo, 2000), uma das causas de afirmação de seu poder. É por essa razão que, nos termos weberianos, o partido é antes de tudo uma associação no seio da comunidade política, independentemente de seus fins ou objetivos, dotada, por isso, de potencial de criação de capital social e político. Nesse ponto, é preciso, como afirma Reis, ter em mente a complexa articulação entre identidade e instrumentalidade exercida pelos partidos, isto é, a relação paradoxal agenciada, ao combinarem valores e interesses no processo político (Reis, 2010).

A natureza da associação realizada pelos partidos está intrinsecamente relacionada a uma formação que luta pela dominação, ou seja, o objetivo é assegurar um campo de exercício de influência e poder, seja pelos recursos econômicos obtidos, pela influência social ou pelo poder de palavra. Nesse último quesito situam-se as estratégias de publicidade política, entendidas como uma forma de propaganda das legendas a fim de consolidar seu poder discursivo e simbólico, nos termos de Bourdieu (1989). Funcionam como revitalizadores da mediação entre os cidadãos e as instituições partidárias. Desse ponto de vista, os partidos servem como mediadores entre a sociedade e o Estado, uma vez que organizam os termos da competição eleitoral.

Analisados pragmaticamente, os partidos são instituições que têm as seguintes funções: a) do ponto de vista do eleitorado, simplificam as escolhas dos cidadãos, mobilizando-os para participar; b) do ponto de vista organizacional, ajudam a recrutar líderes; c) do ponto de vista governamental, participam da criação de maiorias, organizam o governo, principalmente no Legislativo, e organizam a oposição (Dalton e Wattemberg, 2000). Os objetivos podem ser a busca de votos (para cargos), posições sobre políticas ou cargos no poder. Nesse quesito, Manin (2013) destaca que existe uma 
tendência de personalização política, pois as legendas contemporâneas fazem campanhas centradas nos candidatos e nas personalidades deles e dos líderes. Para ele, as siglas conseguiram se adaptar à tendência impulsionada pelos meios de comunicação de massa e, ainda que as eleições tenham se tornado personalizadas, continuam partidárias.

\section{Metodologia do estudo}

A metodologia consistiu no monitoramento e na análise dos websites das legendas, com o propósito de mapear de que forma as temáticas ecológicas são incorporadas pelos programas partidários. O levantamento foi realizado no período de agosto a setembro de 2014, durante a campanha eleitoral. Para tanto foram consideradas as informações oficiais disponíveis no portal da Justiça Eleitoral, complementadas com informações disponíveis nos websites dos próprios partidos. Os websites examinados constam no Quadro 1.

Foram consideradas quatro modalidades de adesão a essa agenda. A primeira consiste na inclusão do tema no corpo do programa partidário. A segunda refere-se à oferta de espaços específicos dos websites destinados ao assunto, como núcleos e secretarias socioambientais. A terceira contempla a oferta de cursos online de educação ambiental. A quarta consiste na divulgação de noticiário sobre temas ambientais. Alguns partidos aderem a apenas uma dessas estratégias, enquanto outros combinam mais de uma delas ou todas, conforme será detalhado no tópico referente à análise dos dados.

Quadro 1

Partidos políticos registrados no TSE até a conclusão da pesquisa

\begin{tabular}{|l|l|l|l|l|}
\hline & Sigla & Legenda & Registro & Website \\
\hline 1 & PMDB & $\begin{array}{l}\text { Partido do Movimento } \\
\text { Democrático Brasileiro }\end{array}$ & 30.6 .1981 & http://pmdb.org.br/ \\
\hline 2 & PTB & $\begin{array}{l}\text { Partido Trabalhista } \\
\text { Brasileiro }\end{array}$ & 3.11 .1981 & http://www.ptb.org.br/ \\
\hline 3 & PDT & $\begin{array}{l}\text { Partido Democrático } \\
\text { Trabalhista }\end{array}$ & 10.11 .1981 & http://www.pdt.org.br/ \\
\hline 4 & PT & Partido dos Trabalhadores & 11.2 .1982 & http://www.pt.org.br/ \\
\hline 5 & DEM & Democratas & 11.9 .1986 & http://www.dem.org.br/ \\
\hline 6 & PCdoB & Partido Comunista do Brasil & 23.6 .1988 & http://www.pcdob.org.br/ \\
\hline 7 & PSB & Partido Socialista Brasileiro & 10.7 .1988 & http://www.psb40.org.br/ \\
\hline 8 & PSDB & $\begin{array}{l}\text { Partido da Social } \\
\text { Democracia Brasileira }\end{array}$ & 24.8 .1989 & http://www.psdb.org.br/ \\
\hline 9 & PTC & Partido Trabalhista Cristão & 22.2 .1990 & http://www.ptc36nacional.com.br/ \\
\hline 10 & PSC & Partido Social Cristão & 29.3 .1990 & http://www.psc.org.br/ \\
\hline 11 & PMN & $\begin{array}{l}\text { Partido da Mobilização } \\
\text { Nacional }\end{array}$ & 25.10 .1990 & http://pmn.org.br/ \\
\hline 12 & PRP & $\begin{array}{l}\text { Partido Republicano } \\
\text { Progressista }\end{array}$ & 29.10 .1991 & http://www.prp.org.br/ \\
\hline 13 & PPS & Partido Popular Socialista & 19.3 .1992 & http://portal.pps.org.br/ \\
\hline
\end{tabular}


POLÍTICA PARTIDÁRIA E MEIO AMBIENTE: A ADESÃO DOS PARTIDOS POLÍTICOS BRASILEIROS À AGENDA VERDE

\begin{tabular}{|c|c|c|c|c|}
\hline & Sigla & Legenda & Registro & Website \\
\hline 14 & PV & Partido Verde & 30.9 .1993 & http://pv.org.br/ \\
\hline 15 & PTdoB & Partido Trabalhista do Brasil & 11.10 .1994 & http://www.ptdob.org.br/home/ \\
\hline 16 & PP & Partido Progressista & 16.11 .1995 & http://www.pp.org.br/ \\
\hline 17 & PSTU & $\begin{array}{l}\text { Partido Socialista dos } \\
\text { Trabalhadores Unificado }\end{array}$ & 19.12.1995 & http://www.pstu.org.br/ \\
\hline 18 & PCB & Partido Comunista Brasileiro & 9.5 .1996 & http://pcb.org.br/portal/ \\
\hline 19 & PRTB & $\begin{array}{l}\text { Partido Renovador } \\
\text { Trabalhista Brasileiro }\end{array}$ & 28.3.1995 & http://prtb.org.br/ \\
\hline 20 & PHS & $\begin{array}{l}\text { Partido Humanista da } \\
\text { Solidariedade }\end{array}$ & 20.3.1997 & http://phs.org.br/ \\
\hline 21 & PSDC & $\begin{array}{l}\text { Partido Social Democrata } \\
\text { Cristão }\end{array}$ & 5.8 .1997 & http://www.psdc.org.br/ \\
\hline 22 & PCO & Partido da Causa Operária & 30.9 .1997 & http://www.pco.org.br/ \\
\hline 23 & PTN & Partido Trabalhista Nacional & 2.10 .1997 & http://www.ptn.org.br/2013/ \\
\hline 24 & PSL & Partido Social Liberal & 2.6 .1998 & http://www.psl.org.br/ \\
\hline 25 & PRB & $\begin{array}{l}\text { Partido Republicano } \\
\text { Brasileiro }\end{array}$ & 25.8 .2005 & http://www.prb10.org.br/ \\
\hline 26 & PSOL & $\begin{array}{l}\text { Partido Socialismo e } \\
\text { Liberdade }\end{array}$ & 15.9.2005 & http://www.psol50.org.br/ \\
\hline 27 & PR & Partido da República & 19.12 .2006 & http://www.partidodarepublica.org.br \\
\hline 28 & PSD & Partido Social Democrático & 27.9.2011 & http://www.psd.org.br/ \\
\hline 29 & PPL & Partido Pátria Livre & 4.10 .2011 & http://partidopatrialivre.org.br/ \\
\hline 30 & PEN & Partido Ecológico Nacional & 19.6 .2012 & http://www.pen51.org.br/ \\
\hline 31 & PROS & $\begin{array}{l}\text { Partido Republicano da } \\
\text { Ordem Social }\end{array}$ & 24.9.2013 & http://http//www.pros.org.br/ \\
\hline 32 & SDD & Solidariedade & 24.9 .2013 & http://www.solidariedade.org.br/ \\
\hline
\end{tabular}

Fonte: <http://www.tse.jus.br/partidos/partidos-politicos>.

A opção pela análise com base nos websites dos partidos se justifica pela crescente relevância do uso de ferramentas digitais pelos partidos políticos e demais instituições políticas, conforme mostram vários estudos recentes. A internet, portanto, constitui uma ferramenta indispensável para a atuação dos partidos. Afinal, no contexto de uma sociedade de multirredes (Bauman, 2000), os partidos (e todas as demais instituições políticas) deparam-se com a lógica da inevitabilidade digital, resultante do processo de encolhimento do mundo (Harvey, 1992) e de constituição de novos modos do fazer político. A internet renovou o campo político, com um novo tipo de copresença, por meio da atuação online dos atores. Ressalta-se nesse aspecto a capacidade de agência do usuário de internet, com sua múltipla atuação (espectador, ator e operador). Os partidos tiveram que aderir, portanto, à política de signos para criar e representar modos de pertencimento do cidadão (Ribeiro, 2000).

No regime de visibilidade da democracia de público, a política informacional (Castells, 2003) torna-se cada vez mais imperativa. Afinal, a geração, o processamento e a transmissão de informações e imagens tornaram-se as fontes fundamentais de produtividade de poder. Por isso, os partidos políticos tendem cada vez mais a recorrer a estratégias de sedução política pela internet, cujos websites são o foco da divulgação, 
uma espécie de "palanque virtual" ou de outdoor na esfera virtual (Castells, 2003). Isso explica ainda por que os partidos "investem progressivamente em estratégias de promoção da personalidade e de democracia de contato". Além disso, "aderem aos recursos midiáticos para captar a atenção pública" (Lipovetsky, 2013, p. 50-51). É oportuno ressaltar que a literatura especializada mostra como a relação entre política e internet tornou-se inevitável, com o uso quase generalizado de websites pelos partidos políticos (Albuquerque e Martins, 2010; Blanchard, 2006; Römmele, 2003; LestonBandeira, 2012).

A internet, como ferramenta de democracia eletrônica, oferece possibilidades de comunicação entre os partidos e os eleitores, inclusive por meio da oferta de informações pouco exploradas pelas mídias convencionais, a exemplo do conteúdo detalhado dos programas partidários. Desse modo, a internet torna-se mais uma alternativa em termos de propaganda política e de construção da imagem partidária, ampliando a esfera da visibilidade política. Afinal, "a política que se exibe, mostra-se, faz-se presença, impõe-se à percepção do cidadão" (Gomes, 2004, p. 403).

Os suportes digitais utilizados pelas legendas para divulgar sua adesão à agenda socioambiental devem ser analisados à luz dessas observações. No caso brasileiro, são oportunas ainda as observações de Carreirão (2012), no que se refere a um balanço das tendências recentes dos partidos políticos brasileiros ${ }^{1}$, especialmente no que diz respeito ao papel do sistema partidário no mercado eleitoral, na arena legislativa e na esfera governamental. Trata-se de uma reflexão ancorada nas ideias de Key (1964) acerca das três principais funções exercidas pelas legendas: sua atuação na arena eleitoral, sua atuação institucional e sua relação com os governos ${ }^{2}$. Resta examinar como as estratégias dos websites das legendas, no que se refere à inclusão das temáticas ambientais, relacionam-se com todas essas funções. Afinal, ao contemplar temas da agenda verde em seus programas partidários, as agremiações políticas tanto dialogam com o eleitorado como afirmam sua identidade institucional e também procuram atuar como mediadores entre a sociedade e as instituições governamentais do Poder Executivo (Veiga, 2007; Amaral, 2013).

Antes da análise dos dados, são apresentadas algumas informações a título de contextualização do artigo, a fim de situar como a agenda ambiental foi incorporada pelos partidos políticos.

\section{Como a agenda ambiental foi incorporada pelos partidos políticos}

Nas primeiras décadas do século $X X$, a ecologia ${ }^{3}$ era tratada de forma episódica e fragmentada, mas, com o passar do tempo, tornou-se um supertema da agenda social e

\footnotetext{
${ }^{1}$ Não é objetivo apresentarmos aqui um estado da arte acerca dos estudos sobre partidos políticos, uma vez que já existe farta bibliografia que engloba o tema. Para mais detalhes, ver Carreirão (2012).

2 Para um detalhamento dessas funções, ver Veiga (2007).

${ }^{3}$ Cabe esclarecer que o termo inicial utilizado para se referir ao pensamento verde era "ecologia". Contudo, com o passar do tempo, passou-se a preferir "ambientalismo". Conforme Pádua (1986), o sentido do
} 
cultural, especialmente após os anos de 1970, ao romper a lógica de assunto eventual da agenda pública para tornar-se problemática sociopolítica com abordagem continuada, complexa e recorrente (Guimarães, 1996). Segundo Ribeiro (2000, p. 158), esse processo deve ser analisado à luz de uma tentativa de reeticização do capital, "ao incorporar em seus cálculos a preocupação com as gerações futuras, o conceito de equidade intergerações, de caráter profundamente moral". Desse modo, conforme a análise do mesmo autor, o ambientalismo assumiu a forma de um metarrelato político, uma espécie de formulação universalista, "que articula e neutraliza interesses divergentes no campo político" (p. 161). Se antes sua configuração era de uma questão outsider, a penetração difusa das ideias ecológicas na política e nas demais esferas da sociedade deu-lhe a dimensão de questão estabelecida, que conquistou posição central no debate político, conforme argumenta Ulrich Beck (Beck, Giddens e Lash, 1994, p. 268).

Antes de serem incorporadas aos programas partidários, as pautas ecológicas e ambientais $^{4}$ passaram por uma longa e complexa trajetória de variados tipos de militantismo ${ }^{5}$. Diversos ecologismos se formaram antes de chamarem atenção dos partidos políticos (Barros e Sousa, 2010). Cada vertente possui a sua própria identidade, visto que cada uma delas constitui um campo particular de disputas, com sua natureza própria, seus interesses, suas lógicas e estratégias. O reconhecimento de tal pluralidade é indispensável para evitar o equívoco do pressuposto de um pensamento ecológico único e monolítico (Barros, 2012).

A recente configuração do pensamento ecológico é tributária de um ideário filosófico e político gestado pelos movimentos que defendiam a transformação do pensamento social, da ordem cultural e do sistema político das sociedades avançadas no contexto político resultante do após Segunda Guerra Mundial (Barros, 2012). Apesar da pluralidade de vertentes há um escopo político geral que reúne referentes simbólicos comuns que levaram o pensamento ambiental a se tornar um movimento planetário ${ }^{6}$, com ampla visibilidade.

Um dos eixos da discussão contemporânea é o socioambientalismo (Alonso e Costa, 2002), derivado de duas perspectivas teóricas: a modernização ecológica ${ }^{7}$ (Buttel,

primeiro situava-se mais no campo do meio natural, enquanto o segundo passou a englobar a cultura e a sociedade. Em suma, no primeiro caso havia certa conotação de externalidade (mundo exterior), enquanto o segundo inclui o homem, a cultura, a sociedade. É nessa acepção que os dois conceitos são utilizados neste artigo.

${ }^{4}$ Há uma vasta discussão na literatura sobre as diferenças e aproximações entre os conceitos de ecologia (o meio natural) e meio ambiente (o meio construído socialmente). Uma cartografia dessas visões é sumarizada por Barros e Sousa (2010).

5 Para uma visão mais detalhada dessa trajetória de militantismos, ver Oliveira (2008).

6 O discurso ecológico amplificou-se a partir das convergências e antinomias peculiares às suas diversas vertentes, desde as mais radicais àquelas que aderiram às retóricas conciliadoras do "capitalismo verde", sob a nomenclatura de desenvolvimento sustentável.

7 Essa vertente considera a perspectiva da sustentabilidade, ou seja, a possibilidade de associar crescimento econômico e proteção ambiental, como base na reestruturação das políticas econômicas em face das novas posturas ambientais. 
2000; Catton e Dunlap, 1980) e a modernização reflexiva ${ }^{8}$ (Beck, Giddens e Lash, 1997). Aliás, é oportuno salientar que a conotação política foi acentuada com o debate sobre as questões de risco (Borraz, 2014) e a ampla inserção da perspectiva dos conflitos ambientais nas arenas de controvérsias públicas (Fleury, Almeida e Premebida, 2014). Tais controvérsias muito contribuíram para a constituição de uma agenda política em nível internacional ${ }^{9}$.

A reflexão fundadora dessa articulação teve como ponto de partida a noção de insustentabilidade da civilização contemporânea. Disso decorre a ideia de que a sustentabilidade será viabilizada social e culturalmente apenas se houver sistemas simbólicos com eficácia para mudar os valores e os comportamentos em um cenário de conflitos e riscos ambientais. Aliás, é oportuno salientar que a conotação política foi acentuada com o debate sobre as questões de risco (Borraz, 2014) e a ampla inserção da perspectiva dos conflitos ambientais nas arenas de controvérsias públicas (Fleury, Almeida e Premebida, 2014).

A propósito, a discussão sobre riscos ambientais carrega consigo uma noção implícita, mas muito relevante para a compreensão sociológica e política contemporânea no que se refere ao conceito de sociedade de risco ${ }^{10}$, uma das abordagens profícuas para a constituição de uma agenda política em nível internacional. Oficialmente, a preocupação política desses atores internacionais com o meio ambiente começou a ser expressa nas primeiras décadas do século XX. Mesmo sem a participação expressiva dos grandes partidos, essa fase foi importante, pois contribuiu para criar as condições para o futuro envolvimento da política partidária em nível mais amplo.

Mesmo sem pretender apresentar uma historiografia completa, destacamos a seguir alguns dos principais documentos e fatos que marcaram o desenvolvimento do pensamento ecológico em termos mundiais (resumidos no Quadro 2), a fim de situar essa fase anterior à atuação partidária, mas de suma relevância do ponto de vista político mais amplo:

\footnotetext{
${ }^{8}$ Segundo essa interpretação, os processos de modernização social incluem, necessariamente, elementos da infraestrutura produtiva do meio rural, os quais passaram a considerar princípios ambientais.

9 Embora o termo "risco" tenha surgido no repertório sociológico em 1986, com a publicação da primeira edição do livro de Beck sobre sociedade do risco (Risikogesellschaft, em alemão), os organismos internacionais já chamavam atenção para as catástrofes ecológicas desde o início da década de 1920, como mostra o Quadro 2.

10 Termo cunhado por Ulrich Beck para designar uma etapa da modernidade ou uma "segunda modernidade" que emerge da globalização e tem como consequência uma cadeia inter-relacionada de riscos sociais, econômicos, políticos e ambientais, que se expressam no consumismo, individualismo, miséria, fome, violência e desastres nucleares, químicos e genéticos.
} 


\section{Quadro 2}

Contexto internacional que originou a globalização da agenda e das políticas ecológicas

\begin{tabular}{|l|l|l|}
\hline Período & \multicolumn{1}{|c|}{ Fato } & \multicolumn{1}{c|}{ Consequências políticas } \\
\hline 1925 & $\begin{array}{l}\text { Assinatura do Protocolo de } \\
\text { Genebra }\end{array}$ & $\begin{array}{l}\text { Proibição do uso de gases tóxicos e do } \\
\text { emprego belicoso de armas bacteriológicas } \\
\text { em operações militares. }\end{array}$ \\
\hline 1958 & $\begin{array}{l}\text { Assinatura da Convenção } \\
\text { Internacional para a } \\
\text { Prevenção da Poluição do } \\
\text { Mar por Óleo }\end{array}$ & $\begin{array}{l}\text { Estabelecimento de medidas governamentais } \\
\text { para evitar poluição marítima. }\end{array}$ \\
\hline $\begin{array}{l}\text { Dssinatura do Acordo } \\
\text { sobre Uso de Armas } \\
\text { Nucleares no espaço } \\
\text { Cósmico, na Atmosfera e } \\
\text { sobre a Água. }\end{array}$ & $\begin{array}{l}\text { Divulgação dos relatórios } \\
\text { do Clube de Roma seus } \\
\text { impactos na comunidade } \\
\text { internacional }\end{array}$ & $\begin{array}{l}\text { Estabelecimento de medidas de proteção do } \\
\text { espaço, da atmosfera e dos oceanos, a fim de } \\
\text { evitar poluição nuclear. }\end{array}$ \\
\hline 1970 & $\begin{array}{l}\text { Relatórios sobre as crises do petróleo; a } \\
\text { limitação dos recursos naturais; a escassez } \\
\text { regime econômico vigente nos países } \\
\text { industrializados e em desenvolvimento; o } \\
\text { elevado crescimento populacional; e modelos } \\
\text { energéticos. }\end{array}$ \\
\hline $\begin{array}{l}\text { Realização da Conferência } \\
\text { seus desdobramo em } 1972 \text { e }\end{array}$ & $\begin{array}{l}\text { Debates políticos e econômicos na fase de } \\
\text { preparativos do evento, com maior ênfase na } \\
\text { etapa dos desdobramentos, ou seja, } \\
\text { praticamente durante toda a década de 1970. }\end{array}$ \\
\hline
\end{tabular}

Fonte: Elaboração do autor, com base em Barros e Sousa (2010).

Um dos marcos políticos da constituição de uma arena internacional de controvérsias públicas sobre ambiente foi a I Conferência da ONU sobre Meio Ambiente e Desenvolvimento, realizada em Estocolmo $(1972)^{11}$. O evento teve como objetivo abordar os problemas ecológicos de forma global, a fim de sensibilizar os governos e nações para a necessidade de cooperação internacional e iniciativas coletivas e consensuais (Figueiredo, 1993). Sob esse impulso, alguns governos dos países centrais deram os passos iniciais rumo às primeiras medidas de política ambiental no mundo ainda na década de 1970, a exemplo do Canadá, Holanda, Suécia e Dinamarca, entre outros. Iniciou-se aí uma longa trajetória de institucionalização da questão ambiental, consagrada politicamente com a criação de órgãos oficiais que potencializaram sua inserção no campo partidário e parlamentar. Assim, o ambiente torna-se um trunfo político, "entrando no jogo institucional da democracia, regido pelos partidos" (Almeida e Premebida, 2014, p. 25).

Nesse contexto é que surgiram os primeiros "partidos verdes", com a inclusão formal do debate na arena eleitoral. Tais legendas começaram a surgir logo após a Conferência de Estocolmo, embora com pouca influência política nos processos decisórios

\footnotetext{
11 Para um panorama dos principais eventos historicamente relevantes para a construção da visibilidade ambiental, ver Barros (2012).
} 
dos parlamentos. A primeira iniciativa teve origem na Tasmânia (Austrália), em 1972, fruto da decisão de um grupo de ecologistas denominado United Tasmanian Group. Posteriormente, o grupo passou a ser denominado Green Party e fundou uma base na Nova Zelândia. Em seguida, o grupo expandiu suas atividades para a Europa, com o apoio de ecologistas da Suécia, Finlândia, Noruega, Suíça, Holanda, Alemanha e França. Atualmente, a filosofia orienta partidos políticos em mais de 120 países. Em 2010, o Partido Verde tornou-se a quarta maior bancada no Parlamento europeu.

No contexto europeu, cabe ressaltar a atuação do Partido Socialista (PS) na França, conforme registram Sainteny (1994) e Duverger (2011). A inclusão formal das temáticas ecológicas no programa partidário do PS teve início em 1972, ano de realização da Conferência de Estocolmo, a primeira conferência da Organização das Nações Unidas (ONU) sobre meio ambiente e desenvolvimento. Trata-se de uma experiência partidária singular de adesão à agenda ecológica, o que se deve a um conjunto de fatores, segundo a análise dos autores citados. Em primeiro lugar destaca-se o debate internacional sobre a crise ecológica global, o que fez da agenda verde um elemento expressivo no debate político e uma temática que passou a ser inevitável nas campanhas eleitorais dos candidatos às eleições presidenciais francesas. Os autores destacam como caso emblemático da inclusão do tema na arena eleitoral a campanha e a eleição de François Mitterrand (1980-1981), quando o PS explorou de forma mais intensiva e enfática a conexão entre o discurso partidário eleitoral e a agenda ecológica, com um conjunto significativo de propostas para conquistar o chamado "voto verde". Entre tais propostas, destacava-se a defesa do desenvolvimento durável ou desenvolvimento sustentável, com críticas ao modelo capitalista de exploração dos recursos naturais e a proposição de soluções socialistas para promover o equilíbrio entre o desenvolvimento econômico e a preservação da natureza, incluindo também a defesa da justiça social, dos direitos humanos e da igualdade social.

O debate sobre desenvolvimento durável proposto pelo PS levou o partido a reforçar a agenda verde no debate político francês e a ressaltar as várias dimensões do discurso ecológico, com ênfase para a articulação entre ecologia política, ecologia social e cultura global. A primeira teria como papel revitalizar a democracia representativa, enquanto as demais exerceriam a função de discutir e apontar novas formas de organização social e de revisão dos sistemas culturais moldados pelo sistema capitalista, pela sociedade de consumo e pelos modelos de crescimento econômico vigentes, de base predatória. Dessa forma, o PS combinou seu discurso de crítica ecológica com a crítica social, política e cultural. Além disso, o partido chamou atenção para temas como novas formas de promoção do desenvolvimento econômico, a exemplo da economia solidária, das inovações tecnológicas em prol do desenvolvimento sustentável e de outras formas industriais ancoradas em projetos de desenvolvimento local, em consonância com os valores e interesses coletivos. 
Isso tudo reforçou e ampliou o escopo do debate partidário sobre a agenda verde. Em suma, a ênfase do PS a questões ambientais contribuiu para colocar a agenda ecológica no debate político partidário francês e nos demais países europeus. Além de surgir como um novo ator partidário emblemático em sua relação com o ambientalismo, o PS estimulou outras legendas a aderir à agenda verde, especialmente os demais partidos de orientação socialista, reforçando os vínculos históricos e as convergências entre os socialistas e os movimentos sociais ecológicos. Assim, a contribuição do PS é apontada por Sainteny (1994) como a transformação do ecologismo em um eixo de reflexão e de ação política. Isso levou a agenda verde a adquirir relevância também nas eleições legislativas francesas, a partir de 1992, conforme explica o autor citado.

No Brasil ${ }^{12}$, o Partido Verde foi fundado em 1986, na cidade do Rio de Janeiro, resultado da reunião de ex-exilados políticos, como ecologistas, artistas, intelectuais e ativistas do movimento antinuclear. Durante a Conferência do Rio, o Partido Verde brasileiro promoveu a Primeira Reunião Planetária dos Verdes. Considerada o maior evento diplomático e político do mundo no que se refere à questão ambiental (Lafer, 1993; Boktin, 1992), a Rio-92 contribuiu para que a agenda ambiental fosse incorporada por partidos políticos de variados espectros ideológicos, com mais ênfase, entretanto, nos denominados partidos de esquerda ou de orientação socialista. Afinal, tal agenda tornou-se transversal, com a adesão de vários atores sociais e políticos, superando a polarização direita x esquerda, com a formação de uma "coalizão verde", "apesar de um leque variado de posturas, perspectivas e receitas de ação" (Giddens, 2010, p. 74). Trata-se do que o autor caracteriza como "a primeira onda política do ambientalismo"13, que consiste "na transposição do problema para a agenda dos assuntos políticos (p. 22). Esse processo retirou dos partidos verdes o controle político-partidário da agenda ambiental, porém, contribuiu para a capilarização e a inserção social no mundo vivido. Os demais partidos, que antes não se ocupavam com tal agenda, foram agenciados pelo discurso ecológico (Bauman, 2000), o que mostra a força da eficácia discursiva da retórica da sustentabilidade, como ressalta Ribeiro (2000). Por outro lado, Latour (1994, p. 80) destaca que os partidos políticos, ao aderirem às causas ecológicas, tornaram-se mediadores e tradutores, ou seja, "atores dotados de capacidade de traduzir aquilo que eles transportam, de redefini-lo, desdobrá-lo, e também de traí-lo".

Mas o que levou os partidos de diferentes orientações ideológicas e defensores de outras causas a apoiar as bandeiras ecológicas? Por que as agendas ecológicas e ambientais transcendem as arenas partidárias e os limites dos chamados partidos verdes? Alguns argumentos são apontados por pensadores como Bobbio (1992),

\footnotetext{
12 Em 1985 foi criado o Núcleo de Ecologistas do Partido dos Trabalhadores. Entretanto, a avaliação é de que a inserção do ambientalismo na política partidária brasileira ocorreu tardiamente, tendo como referência a gênese do militantismo, cujo histórico remete às "elites naturalistas", vinculadas à problemática internacional, surgida na Europa e nos Estados Unidos (Oliveira, 2008).

13 A segunda onda, conforme o autor, "deverá envolver sua introdução em nossas instituições e nas preocupações cotidianas dos cidadãos" (Giddens, 2010, p. 22).
} 
Hobsbawn (1995), Castells (1999), Giddens (2010) e Latour (2004), os quais chamam atenção para a relação histórica do ambientalismo com uma rede de outros atores sociais. Para o primeiro autor, os movimentos em defesa da natureza não devem ser compreendidos como iniciativas isoladas e autônomas, mas como parte de um conjunto de movimentos em defesa dos direitos humanos, incluindo as liberdades individuais, os direitos políticos e sociais. O ambientalismo, na visão de Bobbio, se insere no âmbito da emergência histórica dos chamados direitos de terceira geração (direitos étnicos, de gênero, de imigrantes, qualidade de vida, ecológicos etc.), ou seja, o direito relativo à natureza, no qual os sujeitos não são entendidos como indivíduos, grupos sociais, categorias profissionais ou instituições sociais. Em sua avaliação, nesses direitos de terceira geração, o sujeito é a própria humanidade.

Hobsbawn complementa que esses movimentos apontam para reivindicações que exigem mudanças em toda a estrutura da sociedade e apelam para a adesão generalizada das pessoas e não apenas de categorias específicas. Os direitos ambientais são associados às reivindicações, campanhas e manifestações públicas em prol da paz, da qualidade de vida, da diversidade cultural, da integração sociocultural, do bem-estar geral da humanidade, independentemente de sua raça, religião, gênero ou nacionalidade. Castells (1999) acentua a lógica de redes dos movimentos ecológicos, apesar das diferentes identidades militantes, e também o potencial desses movimentos como agentes e colaboradores da lógica da midiatização, o que aumenta seus poderes em termos de capacidade para captar e dirigir a atenção do público. O autor ressalta a força simbólica que os enquadramentos selecionados pelos media, a partir da ação dos movimentos ecológicos, exercem na formação e difusão da opinião pública, com amplos efeitos reflexivos nas relações e nos próprios movimentos em si. Os demais autores mencionados, além de convergirem para as linhas gerais dos argumentos já apontados, ressaltam ainda o poder de reflexividade das políticas ambientais (Giddens, 2010) e de sua inserção social por meio da fundação de novos pactos de aprendizagem, com as propostas de renovação do contrato social sob a forma de um novo contrato natural pautado por uma ecologia política com novas bases epistêmicas (Latour, 2004).

A amplitude de inserção social reitera o argumento das capilaridades, redes e ramificações, que deságuam na diversificação dos horizontes de sentidos sobre ecologia, na perspectiva da complexidade (Leff, 2009; Morin, 1994). Diante desse multifacetado quadro hermenêutico é que o ambientalismo passou a ser tomado como exemplo paradigmático da perspectiva de ampliação do olhar histórico e político, principalmente pelo seu potencial de integrar saberes, além de permitir problematizações complexas, transversais e transclassistas sobre a realidade social e política. Como resultado disso, as reflexões sobre ambientalismo foram incorporadas pelas demais configurações sociais, ressaltando-se o potencial desse campo ideal político, com amplos impactos na esfera pública (Carvalho, 2006). 
Esse conjunto de fatores é que levou à constituição de comunidades de riscos compartilhados, na expressão de Habermas (1995), referindo-se às transformações na esfera pública a partir de impactos gerados pela crise dos recursos naturais e das alterações climáticas. Tal cenário levou ao que Giddens (2010) denominou de política da vida, que incorpora uma nova cultura política que agrega a preocupação com a natureza ${ }^{14}$. Conforme Inglehart (1981), o ambientalismo insere-se em uma nova ordem de necessidades, que transcende a esfera material e coloca na cena pública o debate sobre temas cuja força principal está no conteúdo simbólico, imaterial e intangível, embora o caráter econômico não seja excluído.

A década de 1980 marcaria o início do avanço ambientalista no contexto brasileiro ${ }^{15}$, com o objetivo de desenvolver política ambiental atenta à gravidade da questão e adequá-la ao contexto internacional. A Lei Federal 6.938/81 criou o Sistema Nacional de Meio Ambiente, que estabeleceu os objetivos, princípios e diretrizes da política ambiental. Com a Constituição de 1988, estados e municípios passam a ter competência para formular suas próprias políticas. No plano institucional, destacam-se a criação do Instituto Brasileiro do Meio Ambiente e dos Recursos Naturais Renováveis (Ibama), em 1989, que passa a ter a missão de formular, coordenar e executar a Política Nacional de Meio Ambiente. A Conferência do Rio marcaria o debate sobre desenvolvimento, sustentabilidade e mudanças climáticas.

Em suma, a emergência dos temas ambientais e sua inserção difusa na agenda dos partidos políticos no Brasil estão diretamente vinculadas à evolução de uma agenda ecológica internacional, conduzida por organismos transnacionais de amplo reconhecimento e com capacidade de intervenção política nos países ocidentais, como a Organização das Nações Unidas (ONU). Por essa razão, a agenda política sobre ambiente teve mais força no plano internacional, sob a condução de organismos e agências internacionais, com maior poder de representação simbólica do que os próprios partidos verdes, com restrita atuação local (Guimarães, 1986).

\section{As temáticas ambientais nos programas partidários brasileiros}

Dos 32 partidos, 20 incluem temáticas da agenda ambiental em seus websites, ou seja, $62,5 \%$. A fim de estabelecer um ranking dos programas partidários analisados e com isso identificar o grau de associação dos partidos à agenda verde, estabelecemos pesos a cada item do Quadro 3, sendo 1,0 o maior da escala. Foram considerados cinco itens no cálculo: (a) se o programa da legenda inclui temas ambientais; (b) como se dá a inserção no programa partidário - se por meio de um capítulo próprio ou de modo avulso no texto; (c) se o partido destina uma secretaria ou núcleo aos temas ambientais no

\footnotetext{
${ }^{14}$ Para uma análise mais detalhadas sobre as contribuições de Habermas e Giddens, consultar Carvalho (2006).

${ }^{15}$ Não é objetivo do artigo fazer uma retrospectiva abrangente sobre a trajetória do ambientalismo no Brasil. Para isso, consultar Pádua (1986) e Viola (1987), entre outros.
} 
website; (d) se há publicação de noticiário ecológico no website; (e) se há oferta de cursos online de educação ambiental.

Esse procedimento permitiu escalonar os documentos analisados em diversos graus de adesão, com variações registradas de 0,30 a 1,00. Apenas o PMDB figura com a pontuação máxima. Em seguida aparecem o PT $(0,80)$ e o PROS $(0,70)$. Na sequência estão PPS, PV, PEN e SDD, com 0,60. Entre os últimos colocados no ranking estão o PSD, com 0,30 e 11 legendas que ficaram com índice final 0,40: PDT, DEM, PCdoB, PSB, PP, PSTU, PCB, PSDC, PCO, PRB e PSOL. Cabe ressaltar que o índice adotado não se aplica ao teor ecológico do conteúdo do programa partidário, mas apenas à aferição do uso das quatro estratégias de visibilidade empregadas nos websites das legendas ${ }^{16}$.

Quanto à incorporação do tema no programa partidário por meio de capítulo ou tópico integral dedicado aos temas ecológicos e ambientais, enquadram-se 16 partidos: PMDB, PCdoB, PDT, PT, DEM, PSB, PPS, PV, PP, PSTU, PCB, PSDC, PCO, PRB, PSOL e $P E N$. Em relação às legendas que contemplam parcialmente esse requisito, ao inserir os temas em questão de forma dispersa e assistemática no texto do programa partidário, estão três legendas: PTB, PSD e PROS. O SDD contempla uma secretaria que inclui meio ambiente, com noticiário sobre o tema, mas não trata da agenda verde explicitamente em seu programa partidário. Trata-se da Secretaria do Negro, Índio, Meio Ambiente e Minorias $^{17}$.

\footnotetext{
${ }^{16}$ É necessário explicitar e questionar aqui as limitações da pesquisa documental que embasou o artigo, cujo eixo são as informações disponíveis nos programas dos partidos. Como se trata de uma pesquisa documental, de natureza exploratória e descritiva, faltam elementos de maior densidade analítica que permitam interpretações sociológicas e políticas mais abrangentes a respeito da história, da estrutura e das lógicas próprias de cada partido político e suas relações de concorrência eleitoral. Isso dificulta o acionamento de elementos empíricos extradocumentais que possibilitem explicar seus posicionamentos atuais em relação à temática e sua posição nas disputas eleitorais. Para tal aprofundamento seria necessária uma pesquisa qualitativa mais extensa, que permitisse um trabalho hermenêutico de maior envergadura. A despeito de tais ponderações, consideramos válido o esforço inicial apresentado pelo artigo, no que se refere à classificação e descrição das semelhanças e diferenças entre os programas dos partidos quanto ao vínculo com a temática ecológica. Cabe ressaltar que a pesquisa terá prosseguimento, a fim de aprofundar a análise.

17 Disponível em: <http://www.solidariedade77.org.br/secretarias/negro-indio-meio-ambiente-eminorias/>. Acesso em: 3 set. 2014.
} 
Quadro 3

Inserção de temáticas ambientais nos programas partidários

\begin{tabular}{|c|c|c|c|c|c|c|c|c|c|c|c|c|}
\hline \multirow[b]{2}{*}{1} & \multirow{2}{*}{$\begin{array}{l}\text { Partido } \\
\text { PMDB }\end{array}$} & \multicolumn{2}{|c|}{$\begin{array}{c}\text { Ocorrência/ } \\
\text { Peso }\end{array}$} & \multicolumn{2}{|c|}{$\begin{array}{c}\text { Inserção no } \\
\text { Programa/ } \\
\text { Peso }\end{array}$} & \multicolumn{2}{|c|}{$\begin{array}{c}\text { Núcleo/ } \\
\text { Secretaria/ } \\
\text { Peso }\end{array}$} & \multicolumn{2}{|c|}{$\begin{array}{l}\text { Noticiário } \\
\text { ambiental }\end{array}$} & \multicolumn{2}{|c|}{ EAD/Peso } & \multirow{2}{*}{$\begin{array}{c}\begin{array}{c}\text { Índice } \\
\text { geral }\end{array} \\
1,00\end{array}$} \\
\hline & & Sim & 1,0 & Capítulo & 1,0 & Sim & 1,0 & Sim & 1,0 & Sim & 1,0 & \\
\hline 2 & PTB & Sim & 1,0 & Avulso & 0,5 & Sim & 1,0 & Não & 0,0 & Não & 0,0 & 0,50 \\
\hline 3 & PDT & Sim & 1,0 & Capítulo & 1,0 & Não & 0,0 & Não & 0,0 & Não & 0,0 & 0,40 \\
\hline 4 & PT & Sim & 1,0 & Capítulo & 1,0 & Sim & 1,0 & Sim & 1,0 & Não & 0,0 & 0,80 \\
\hline 5 & DEM & Sim & 1,0 & Capítulo & 1,0 & Não & 0,0 & Não & 0,0 & Não & 0,0 & 0,40 \\
\hline 6 & PCdoB & Sim & 1,0 & Capítulo & 1,0 & Não & 0,0 & Não & 0,0 & Não & 0,0 & 0,40 \\
\hline 7 & PSB & Sim & 1,0 & Capítulo & 1,0 & Não & 0,0 & Não & 0,0 & Não & 0,0 & 0,40 \\
\hline 8 & PPS & Sim & 1,0 & Capítulo & 1,0 & Não & 0,0 & Não & 0,0 & Sim & 1,0 & 0,60 \\
\hline 9 & PV & Sim & 1,0 & Capítulo & 1,0 & Não & 0,0 & Não & 0,0 & Sim & 1,0 & 0,60 \\
\hline 10 & PP & Sim & 1,0 & Capítulo & 1,0 & Não & 0,0 & Não & 0,0 & Não & 0,0 & 0,40 \\
\hline 11 & PSTU & Sim & 1,0 & Capítulo & 1,0 & Não & 0,0 & Não & 0,0 & Não & 0,0 & 0,40 \\
\hline 12 & PCB & Sim & 1,0 & Capítulo & 1,0 & Não & 0,0 & Não & 0,0 & Não & 0,0 & 0,40 \\
\hline 13 & PSDC & Sim & 1,0 & Capítulo & 1,0 & Não & 0,0 & Não & 0,0 & Não & 0,0 & 0,40 \\
\hline 14 & PCO & Sim & 1,0 & Capítulo & 1,0 & Não & 0,0 & Não & 0,0 & Não & 0,0 & 0,40 \\
\hline 15 & PRB & Sim & 1,0 & Capítulo & 1,0 & Não & 0,0 & Não & 0,0 & Não & 0,0 & 0,40 \\
\hline 16 & PSOL & Sim & 1,0 & Capítulo & 1,0 & Não & 0,0 & Não & 0,0 & Não & 0,0 & 0,40 \\
\hline 17 & PSD & Sim & 1,0 & Avulso & 0,5 & Não & 0,0 & Não & 0,0 & Não & 0,0 & 0,30 \\
\hline 18 & PEN & Sim & 1,0 & Capítulo & 1,0 & Não & 0,0 & Não & 0,0 & Sim & 1,0 & 0,60 \\
\hline 19 & PROS & Sim & 1,0 & Avulso & 0,5 & Sim & 0,0 & Sim & 1,0 & Não & 0,0 & 0,70 \\
\hline 20 & SDD & Sim & 1,0 & - & 0,0 & Sim & 0,0 & Sim & 1,0 & Não & 0,0 & 0,60 \\
\hline
\end{tabular}

Fonte: Elaboração do autor, com base em dados de pesquisa própria.

A criação de núcleo ou secretaria socioambiental nos websites, a oferta de cursos online de educação ambiental e a divulgação de noticiário ecológico constituem estratégias complementares. Os núcleos e secretarias oferecem a vantagem de apresentar um lugar de destaque na arquitetura dos websites, com localização privilegiada. Esse recurso é usado por alguns partidos como forma de estabelecer contato direto com alguns segmentos da sociedade. Por essa razão, os núcleos e secretarias socioambientais figuram junto com aqueles destinados aos jovens, mulheres e negros. Adotam essas estratégias os seguintes partidos: PMDB, PT, PROS e SDD, como mostra o Quadro 3.

Outra forma de inserção das temáticas ambientais nos conteúdos oferecidos pelos partidos em seus websites é por meio de cursos online de educação socioambiental, uma estratégia que se insere na oferta de cursos voltados para a formação e a educação política ${ }^{18}$. A educação socioambiental é oferecida pelos seguintes

18 Dos 32 partidos, 28 adotam projetos e estratégias permanentes de educação política, conforme levantamento de Barros, Bernardes e Rodrigues (2014). Apenas o PRP, PSOL, PPL e SDD ainda não estavam engajados em tais projetos até a conclusão do levantamento. É oportuno ressaltar que a Lei dos Partidos Políticos (Lei Federal 9.096/1995) estabelece que as legendas devem aplicar 20\% dos recursos 
partidos: PV, PEN, PPS e PMDB (Quadro 3). Os cursos consistem em divulgar conteúdos para promover a consciência ecológica cidadã. No caso dos dois primeiros trata-se de uma estratégia de educação vinculada ao perfil partidário ${ }^{19}$. Os demais tentam incorporar a temática no âmbito da educação política em termos mais abrangentes, vinculando a educação socioambiental à noção de cidadania.

Antes de prosseguir na análise dos dados, cabe uma breve observação acerca do elenco de partidos que ainda não aderiram à agenda ambiental e, portanto, não adotam nenhuma das estratégias mencionadas acima. São 12 legendas, conforme mostra o Quadro 4, quase todas de pequeno porte e em fase de consolidação de sua identidade e de suas bandeiras, exceto o PSDB.

\section{Quadro 4 \\ Legendas que não tratam de temáticas ambientais nos programas partidários}

\begin{tabular}{|l|c|c|}
\hline & Partidos & Ocorrência \\
\hline 1 & PSDB & Não \\
\hline 2 & PTC & Não \\
\hline 3 & PSC & Não \\
\hline 4 & PMN & Não \\
\hline 5 & PRP & Não \\
\hline 6 & PTdoB & Não \\
\hline 7 & PRTB & Não \\
\hline 8 & PHS & Não \\
\hline 9 & PTN & Não \\
\hline 10 & PSL & Não \\
\hline 11 & PR & Não \\
\hline 12 & PPL & Não \\
\hline
\end{tabular}

Fonte: Elaboração do autor, com base em dados de pesquisa própria.

No caso do PSDB, contudo, é oportuno ressaltar que a agenda socioambiental assumiu um lugar privilegiado no programa de governo de seu candidato à Presidência da República em 2014, Aécio Neves, provavelmente em função da concorrência eleitoral com Marina Silva. Com um robusto capítulo denominado "Sustentabilidade" e um perfil de governança ambiental centrado no desenvolvimento com sustentabilidade econômica,

oriundos do Fundo Partidário para atividades de educação política, além de manutenção de institutos de pesquisa e doutrinação.

${ }_{19}$ Os partidos utilizam uma variedade de estratégias para a formação política, mas priorizam a formação jovem e a formação ampla. A primeira inclui informações sobre políticas públicas para a juventude, modos de participação dos jovens na política e como os partidos atuam na promoção da cidadania juvenil. A segunda compreende a oferta de conteúdos nos websites voltados para temas abrangentes relacionados à política, como democracia, sistema eleitoral, cidadania, direitos sociais, coletivos e civis, como mostram Barros, Bernardes e Rodrigues (2014). 
o plano do presidenciável do PSDB apresentou propostas de adoção de mecanismos para conciliar crescimento econômico e sustentabilidade, com prioridade para mobilidade urbana, energia e saneamento básico. Segundo a proposta de Aécio Neves, a Presidência da República deveria assumir o protagonismo político nas questões de sustentabilidade, "visando garantir um efetivo diálogo horizontal na esfera federal, com o engajamento dos estados, municípios, setor empresarial e a sociedade civil" (Plano de Governo. Aécio Neves, PSDB, p. 73) ${ }^{20}$. Isso implica "adoção de um modelo de governança matricial, atribuindo responsabilidades ambientais às instâncias governamentais encarregadas das políticas setoriais, com metas de qualidade ambiental a serem cumpridas" (p. 73). Outra prioridade, segundo o texto, são investimentos para garantir a transição para uma economia de baixo carbono "para o enfrentamento do aquecimento global".

\section{Eixos temáticos destacados nos programas partidários}

O mapeamento dos temas centrais dos programas partidários, no que se refere à questão ambiental, revelou quatro grandes eixos temáticos adotados pelos partidos: (a) preservação e conservação; (b) críticas ao sistema capitalista e sustentabilidade ecológica; (c) desenvolvimento com sustentabilidade econômica; (d) ecologia política, cultura urbana e cidadania ecológica. Cada eixo temático apresenta um conjunto de palavras-chave, conforme exposto anteriormente.

Os quatro eixos temáticos adotados se relacionam com as dimensões da sustentabilidade, conforme a classificação de Sachs ${ }^{21}$ (1993): sustentabilidade econômica, social, ecológica, espacial/geográfica e cultural. Segundo o autor, a sustentabilidade econômica ${ }^{22}$ é focada na eficiência na alocação e gestão de recursos extraídos da natureza, além de racionalidade nos investimentos. Esses requisitos contemplam diretamente as ideias contidas nos programas dos partidos defensores do crescimento econômico, como o PMDB, o PT, o PRB e PSB.

A sustentabilidade social prioriza políticas de desenvolvimento humano, com o propósito de promover justiça social e reduzir desigualdades. A sustentabilidade

\footnotetext{
${ }^{20}$ Disponível em: <http://divulgacand2014.tse.jus.br/divulga-cand2014/proposta/eleicao/2014/idEleicao/143/UE/BR/candidato/280000000085/idarquivo/229?x=1404680555 $000280000000085>$. Acesso em: 21 ago. 2014.

21 O autor destaca cinco dimensões do desenvolvimento sustentável: social, econômica, ecológica, espacial/geográfica e cultural. A sustentabilidade espacial refere-se às políticas para a ocupação do solo e relação campo-cidade, por exemplo. A sustentabilidade cultural consiste no respeito às tradições, comunidades nativas e ao patrimônio cultural. Os planos analisados não se detêm em propostas para as duas últimas dimensões.

22 É importante destacar que tal concepção surge no âmbito do conceito de desenvolvimento sustentável, cuja matriz é o projeto desenvolvimentista liberal aplicado ao meio ambiente. "Desde a Conferência de Estocolmo, em 1972, ficou claro que a preocupação dos organismos internacionais quanto ao meio ambiente era produzir uma estratégia de gestão desse ambiente, em escala mundial, que atendesse a sua preservação dentro de um projeto desenvolvimentista. Dentro dessa perspectiva produtivista, o que se queria preservar de fato era um modelo de acumulação de riquezas em que o patrimônio natural passava a ser um bem" (Carvalho, 1991, p. 11). Trata-se, portanto, nas palavras de B. S. Santos (2010, p. 275), de um "processo de politização do espaço da produção".
} 
ecológica, por sua vez, tem como pilar a preservação das fontes de recursos energéticos e naturais, com base na premissa de que o uso econômico dos bens naturais deve considerar os ciclos temporais inerentes às especificidades de cada ecossistema, a fim de garantir o equilíbrio da biodiversidade. Os programas do PCdoB, PDT, PSOL, PCO, PSTU e PCB conjugam propostas que contemplam as três dimensões da sustentabilidade citada, conforme mostra o Quadro 5.

A sustentabilidade espacial refere-se às políticas para a ocupação do solo e relação campo-cidade, por exemplo. A sustentabilidade cultural consiste no respeito a tradições, comunidades nativas e patrimônio cultural. Os planos analisados não se detêm em propostas para as duas últimas dimensões. Cabe ressaltar o perfil dos dois partidos tipicamente ecológicos (PV e PEN), os dois únicos que contemplam as cinco dimensões da sustentabilidade ${ }^{23}$. Para essas legendas as questões ambientais são abrangentes e se inserem em todas as dimensões da vida social, no plano local e global, reunindo o patrimônio natural e a diversidade cultural.

O bloco preservacionista, que reúne PP, PSDC, PSD, PTB e DEM, corresponde à combinação da sustentabilidade econômica, social e ecológica.

\footnotetext{
${ }^{23}$ No caso do PV e do PEN cabem algumas observações sobre a história e as lógicas específicas de atuação de cada um deles, o que auxilia na compreensão do vínculo dessas duas legendas com a agenda verde atual. O PV foi criado em 1986, sob influência de movimentos ecológicos internacionais que defendiam o pacifismo, a justiça social, a cultura de paz e a igualdade social. Seu discurso tem como base a ecologia política e social de forma abrangente (Barros e Sousa, 2010). O PEN foi criado em 2012, com o propósito de apresentar-se como uma alternativa específica para a formulação de políticas de sustentabilidade em nível nacional. Em vez de uma visão ecológica abrangente, O PEN defende um ambientalismo não radical e mais específico, com foco em temas como recuperação das matas ciliares, cuidados com o lixo e energia solar (Oliveira, 2012).
} 
Quadro 5

Partidos agrupados por eixos temáticos e termos-chave

\begin{tabular}{|c|c|c|c|c|}
\hline Partidos & $\mathbf{N}$ & $\begin{array}{l}\text { Eixos } \\
\text { temáticos }\end{array}$ & $\begin{array}{l}\text { Sustentabilidade } \\
\text { correspondente }\end{array}$ & $\begin{array}{l}\text { Termos-chave convergentes e } \\
\text { mais citados nos programas } \\
\text { partidários }\end{array}$ \\
\hline $\begin{array}{l}\text { PP, PSDC, } \\
\text { PSD, PTB, } \\
\text { PPS, DEM }\end{array}$ & 6 & $\begin{array}{l}\text { Preservação e } \\
\text { desenvol- } \\
\text { vimento }\end{array}$ & $\begin{array}{l}\text { Sustentabilidade } \\
\text { econômica, social e } \\
\text { ecológica }\end{array}$ & $\begin{array}{l}\text { Preservação, conservação, proteção } \\
\text { da natureza, responsabilidade } \\
\text { ambiental, desenvolvimento } \\
\text { sustentável, defesa da } \\
\text { biodiversidade, uso racional dos } \\
\text { recursos renováveis. }\end{array}$ \\
\hline $\begin{array}{l}\text { PCdoB, PDT, } \\
\text { PSOL, PCO, } \\
\text { PSTU, PCB }\end{array}$ & 6 & $\begin{array}{l}\text { Críticas ao } \\
\text { sistema } \\
\text { capitalista }\end{array}$ & $\begin{array}{l}\text { Sustentabilidade } \\
\text { ecológica }\end{array}$ & $\begin{array}{l}\text { Poluição, deterioração ambiental, } \\
\text { degradação, destruição ambiental, } \\
\text { devastação florestal, esgotamento } \\
\text { dos recursos naturais, contaminação } \\
\text { do solo, qualidade de vida, fauna e } \\
\text { flora, defesa da ecologia. }\end{array}$ \\
\hline $\begin{array}{l}\text { PMDB, PT, } \\
\text { PRB, PPS }\end{array}$ & 4 & $\begin{array}{l}\text { Desenvolvi- } \\
\text { mento } \\
\text { econômico }\end{array}$ & $\begin{array}{l}\text { Sustentabilidade } \\
\text { econômica }\end{array}$ & $\begin{array}{l}\text { Prosperidade econômica, } \\
\text { desenvolvimento sustentável, } \\
\text { responsabilidade ambiental, crise } \\
\text { ambiental, monitoramento ecológico, } \\
\text { vigilância ambiental, energia } \\
\text { renovável. }\end{array}$ \\
\hline PV, PEN & 2 & $\begin{array}{l}\text { Ecologia } \\
\text { política e } \\
\text { cidadania } \\
\text { ecológica }\end{array}$ & $\begin{array}{l}\text { Sustentabilidade } \\
\text { econômica, social, } \\
\text { ecológica, cultural e } \\
\text { espacial }\end{array}$ & $\begin{array}{l}\text { Ecologia política, ecologia urbana, } \\
\text { desarmamento, cultura de paz, } \\
\text { ecodesenvolvimento, preservação e } \\
\text { recuperação ambiental, tecnologias } \\
\text { limpas, direitos humanos, } \\
\text { participação política, culturas } \\
\text { tradicionais, patrimônio cultural, } \\
\text { desenvolvimento regional. }\end{array}$ \\
\hline
\end{tabular}

Fonte: Elaboração do autor, com base em dados de pesquisa própria.

A partir das propostas reunidas acima, é possível identificar quatro modelos de governança ambiental defendidos pelos partidos ${ }^{24}$, conforme exposto no Quadro 6:

24 Os quatro modelos de governança aqui apresentados foram categorizados a partir da análise documental, com base no texto dos programas partidários. Uma análise capaz de oferecer subsídios interpretativos sobre os perfis partidários de forma mais abrangente requer estudos complementares, com base em outras fontes de pesquisa, empreitada que faz parte dos desdobramentos e continuidades do estudo inicial aqui exposto. 


\section{Perfil partidário de governança ambiental}

\begin{tabular}{|l|l|l|l|l|}
\hline \multicolumn{1}{|c|}{ Partidos } & N & Perfil partidário & $\begin{array}{l}\text { Propostas de políticas } \\
\text { ambientais }\end{array}$ & Papel do Estado \\
\hline $\begin{array}{l}\text { PP, PSDC, } \\
\text { PSD, PTB, } \\
\text { PPS, DEM }\end{array}$ & 6 & Preservacionistas & $\begin{array}{l}\text { Medidas para intensificar } \\
\text { projetos de recuperação } \\
\text { ambiental para restabelecer } \\
\text { o equilíbrio dos } \\
\text { ecossistemas. }\end{array}$ & $\begin{array}{l}\text { Guardião das políticas } \\
\text { de preservação. }\end{array}$ \\
\hline $\begin{array}{l}\text { PCdoB, PDT, } \\
\text { PSOL, PCO, } \\
\text { PSTU, PCB }\end{array}$ & 6 & $\begin{array}{l}\text { Críticos ao } \\
\text { sistema } \\
\text { capitalista }\end{array}$ & $\begin{array}{l}\text { Defesa de mudanças } \\
\text { estruturais no sistema } \\
\text { produtivo. Propostas } \\
\text { utópicas de superação da } \\
\text { ordem capitalista. }\end{array}$ & $\begin{array}{l}\text { Agente de construção } \\
\text { de uma nova ordem } \\
\text { econômica. }\end{array}$ \\
\hline $\begin{array}{l}\text { PMDB,PT, } \\
\text { PRB, PPS }\end{array}$ & 4 & $\begin{array}{l}\text { Adoção de mecanismos para } \\
\text { conciliar crescimento } \\
\text { econômico e } \\
\text { sustentabilidade nas } \\
\text { políticas agrícolas, } \\
\text { energéticas, hídricas e de } \\
\text { ciência, tecnologia e } \\
\text { inovação. }\end{array}$ & $\begin{array}{l}\text { Indutor da } \\
\text { sustentabilidade. }\end{array}$ \\
\hline tistas & $\begin{array}{l}\text { Transformaçães } \\
\text { sociopolíticas e culturais } \\
\text { sistêmicas e integradas. } \\
\text { Associação entre democracia } \\
\text { e cidadania ecológica. } \\
\text { Ecologia como expressão de } \\
\text { justiça social e de direitos } \\
\text { humanos. }\end{array}$ & $\begin{array}{l}\text { Regulador da ecologia } \\
\text { política / ecologia } \\
\text { urbana e indutor da } \\
\text { nova cultura } \\
\text { ambiental. }\end{array}$ \\
\hline PV, PEN & 2 & $\begin{array}{l}\text { Ecologistas } \\
\text { sistêmicos }\end{array}$ & & \\
\hline
\end{tabular}

Fonte: Elaboração do autor, com base em dados de pesquisa própria.

Todos os modelos de governança apresentam em comum a defesa de mudanças no sistema produtivo, com vistas à sustentabilidade, na perspectiva da modernização ecológica (Catton e Dunlap, 1980) e da sustentabilidade econômica (Sachs, 1993). Entretanto, existem diferenças que devem ser ressaltadas. Os preservacionistas defendem como prioridade amplos projetos de recuperação dos biomas a fim de restabelecer o equilíbrio ambiental. Isso é visto como requisito para a retomada de projetos de desenvolvimento econômico. Os desenvolvimentistas, por sua vez, colocam em primeiro plano o crescimento econômico, mas segundo os princípios da sustentabilidade. Os críticos ao capitalismo apegam-se a visões marxistas, com um modelo estatal capaz de reestruturar o sistema produtivo. Os ecologistas sistêmicos são os defensores de uma ordem ecológica complexa, capaz de religar saberes, políticas e práticas sociais. Trata-se de uma concepção calcada na visão de complexidade, nos termos de Morin $(1994)^{25}$.

\footnotetext{
25 Para o autor, a complexidade é entendida como a organização dos contrários, ou seja, uma forma paradoxal de pensar a realidade e ainda um modo de superar as antigas dualidades e ressaltar os paradoxos. Trata-se de uma abordagem epistemológica de reorganizar perspectivas, eventos, ações, interações, retroações, determinações, acasos, que constituem o mundo fenomênico.
} 
Em todos os modelos de governança, o Estado exerce um papel central como ator das políticas ambientais propostas pelos partidos. Trata-se de uma concepção próxima à ideia de Giddens (2010) de Estado assegurador, ou seja, significa que "o Estado é responsável por monitorar os objetivos políticos e por procurar certificar-se de que eles se concretizem de forma visível e aceitável" (p. 96).

\section{Partidos preservacionistas: sustentabilidade ecológica e social}

Chama atenção a quantidade de preservacionistas, com seis partidos que enfatizam em seus programas as questões relacionadas à preservação e à conservação ambiental: PP, PSDC, PSD, PTB, PPS e DEM. No programa do $\mathrm{PP}^{26}$, a preservação do meio ambiente é apresentada como um dos princípios progressistas, embora não haja detalhamento das propostas da legenda quanto a isso.

$\mathrm{O}_{\mathrm{PSDC}}{ }^{27}$ inclui o assunto no tópico sobre os seus objetivos no plano social, com o propósito de "proteger o meio ambiente e assegurar a todos o direito de usufruir da natureza sem agredi-la".

O PSD incorpora o tema no rol de seus princípios e valores ${ }^{28}$ :

o PSD apoia e defende a preservação do meio ambiente como fator de sobrevivência do homem e da própria vida do planeta. É possível alargar as fronteiras da produção, de maneira sustentável e responsável (PSD, Princípios e valores, s.p.).

O PTB atribui ao Estado a responsabilidade pela promoção de medidas em prol desse modelo de desenvolvimento, incluindo ainda o monitoramento ecológico, a fiscalização de políticas de vigilância sanitária e de qualidade ambiental no meio urbano e nos contextos rurais. A legenda também prioriza o desenvolvimento combinado com a preservação dos recursos naturais, conforme consta no item $V$ de seu programa partidário ${ }^{29}$ :

o PTB considera imprescindível que a exploração dos recursos naturais seja feita de maneira racional, estabelecendo-se 0 equilíbrio entre 0 desenvolvimento econômico e a proteção do meio ambiente. Fiel ao princípio do desenvolvimento sustentado, o PTB entende ainda que o meio ambiente e os recursos naturais constituem patrimônio do homem e defende sua exploração racional, de tal forma que sejam legados através das gerações (PTB, Programa partidário, s.p.).

26 Disponível em: <http://www.pp.org.br/textos/453/27435/ProgramaPartidario/?slT=119032>. Acesso em: 5 set. 2014.

27 Disponível em: <http://www.psdc.org.br/sobre-nos/programa/>. Acesso em: 27 nov. 2014.

28 Disponível em: <http://www.psd.org.br/principios-e-valores/>. Acesso em: 27 nov. 2014.

29 Disponível em: <http://www.ptb.org.br/?page=ConteudoPage\&cod=325>. Acesso em: 5 set. 2014. 
Ainda na mesma trilha, a proposta do PPS $^{30}$ contempla "uma agenda de mudanças profundas na forma de fazer política e no modelo de desenvolvimento social e econômico". Isso implica "um modelo de desenvolvimento profundamente comprometido com a democracia e com a sustentabilidade", além de "planejar uma transição estratégica para o desenvolvimento de novo tipo". Conforme o texto, é necessário "posicionar o Brasil na realidade global marcada por crise ambiental". Para a legenda, "é mister aproveitar a privilegiada condição do Brasil", como país detentor de reconhecido patrimônio natural e diversidade cultural:

O Brasil abriga parte significativa da biodiversidade e da água doce existente no planeta, grande extensão de terras cultiváveis, diversidade étnicocultural, bem como uma rica variedade de formações naturais cujo papel é fundamental no equilíbrio climático continental e global. No entanto, as instituições políticas e os sucessivos governos, nas últimas décadas, não têm absorvido e dado relevo ao papel crucial da sustentabilidade no processo de desenvolvimento (PPS, Programa partidário, s.p.).

No programa partidário do $\mathrm{DEM}^{31}$, as propostas ambientais são contempladas no rol dos princípios do partido, cujo propósito é

propugnar por um desenvolvimento que vise à realização integral do homem, a partir de um processo de mudança qualitativa nas relações sociais, voltado para a prosperidade econômica, equidade social e equilíbrio regional, assentado em um relacionamento harmonioso com o nosso patrimônio ecológico e consentâneo com nossa cultura (DEM, Princípios do Democratas, p. 2).

Em todos os programas partidários mencionados, as ideias de cunho preservacionistas apresentam paralelos com o pensamento conservacionista, uma das vertentes primárias do ambientalismo brasileiro. Trata-se de uma abordagem de orientação biocêntrica que defende a natureza como um valor a ser preservado, mediante a patrimonialização de áreas naturais específicas. $O$ movimento conservacionista é herdeiro das mobilizações típicas do final do século XIX, lideradas por uma elite de naturalistas influenciados pelas ideias oriundas de países europeus e dos Estados Unidos, no que se refere a conservação e preservação de paisagens e recursos naturais, assim como de espécies animais, florestas e lagos (Pádua, 1990; Oliveira, 2008). Esse movimento deu impulso e suporte à criação de entidades ecológicas de

\footnotetext{
${ }^{30}$ Disponível em:

<http://www2.pps.org.br/2005/index.asp?portal=\&id_municipio=\&opcao=documentos\&id_categoria $=3 \&$ fla $\mathrm{g}=\mathrm{s}>$. Acesso em: 5 set. 2014.

31 Disponível em: <http://www.dem.org.br/wp-content/uploads/2011/01/Principios-do-Democratas.pdf>. Acesso em: 5 set. 2014.
} 
caráter preservacionista, cujo emblema foi a criação da Fundação Brasileira para Conservação da Natureza (FBNC), em 1958, no Rio de Janeiro. Inspirados em associações de ativistas europeus, as entidades conservacionistas brasileiras eram formadas basicamente por cientistas naturais, jornalistas, políticos e intelectuais de variadas áreas de conhecimento (Oliveira, 2008).

\section{Partidos críticos à ordem capitalista: sustentabilidade ecológica}

Em quantidade igual à do bloco anterior, seis legendas têm como foco de seu programa partidário, no que se refere à questão ambiental, críticas ao sistema capitalista: PCdoB, PDT, PSOL, PCO, PSTU e PCB. Apesar dessa convergência, em termos gerais, cada partido apresenta suas particularidades. $\mathrm{O} \mathrm{PCdoB}^{32}$ associa o esgotamento dos recursos naturais com "a grande crise do capitalismo da época atual". Segundo o texto, o capitalismo é um sistema esgotado historicamente, "busca do lucro máximo, destrói a natureza".

No caso do $\mathrm{PDT}^{33}$, as propostas são condensadas no sexto compromisso de seu programa:

O sexto compromisso programático é com a defesa da natureza brasileira, contra a poluição e a deterioração do meio ambiente resultante de uma exploração predatória, que ameaça destruir a base biológica de nossa existência, degradando cada vez mais a qualidade de vida do povo brasileiro. Depois de empobrecer radicalmente e destruir a fauna e a flora de todas as regiões brasileiras de antiga ocupação, agora ameaçam liquidar com a Amazônia, que é a nossa última reserva da natureza original. 0 Trabalhismo Democrático propugna por um movimento e uma legislação que defendam o ambiente natural do país e coíbam as diversas formas de poluição e pela implementação de um amplo programa nacional de descontaminação (PDT, Compromissos prioritários, p. 1).

O PSOL ${ }^{34}$ insere a questão ecológica no contexto mais amplo do socialismo com democracia, como princípio estratégico na superação da ordem capitalista. Dessa forma, o partido propõe:

A construção de um ideário de superação do processo capitalista reúne hoje, além dos tradicionais pressupostos socialistas, um grande impulso ainda mais vital ligado à questão ecológica. Esse fator pode contribuir decisivamente na reorganização dos trabalhadores internacionalmente.

\footnotetext{
32 Disponível em: <http://www.pcdob.org.br/documento.php?id_documento_arquivo=1>. Acesso em: 5 set. 2014.

33 Disponível em <http://www.pdt.org.br/index.php/pdt/programa/1-compromissos-prioritarios>. Acesso em: 5 set. 2014.

${ }^{34}$ Disponível em: <http://www.psol50.org.br/site/paginas/2/programa>. Acesso em: 5 set. 2014.
} 
Tendo claro que as forças de destruição irracionais acumuladas pelo sistema ameaçam o conjunto da humanidade e da vida no planeta, de tal forma que a luta contra o capitalismo significa a luta em defesa da ecologia, do meio ambiente e da vida, o novo partido elaborará sua plataforma ecológica com a intervenção direta do movimento ecológico nos próximos meses (PSOL, Programa partidário, s.p.).

O documento do PSOL apresenta um capítulo denominado "Política econômica e modelo de desenvolvimento", no qual defende que a proposta de construção de um novo modelo econômico requer "uma profunda revisão do sistema agrário brasileiro". Além de uma reforma agrária profunda,

que desmonte o latifúndio e desaproprie propriedades que possam ser utilizadas para fins produtivos - sobretudo a produção de alimentos - será papel do Estado incentivar atividades que gerem empregos, desenvolvam de forma sustentável a economia no campo e fortaleçam a soberania nacional (PSOL, Programa partidário, s.p.).

O PSOL apresenta como diferencial a prioridade no que se refere às políticas agrárias de desenvolvimento, ao resgatar uma antiga bandeira dos partidos de esquerda. Mais uma vez, a figura do Estado assegurador é central, mas com o propósito específico de regular e institucionalizar planos de reforma agrária para o campo, a fim de aumentar a produção de alimentos e promover o desenvolvimento local e regional.

Duas representações do ambiente rural são evocadas e contrapostas: o cenário atual, marcado pelo latifúndio improdutivo, e um possível cenário futuro, de pequenas propriedades produtivas. A segunda visão reflete diretamente a concepção do socioambientalismo (Alonso e Costa, 2002), segundo a qual o rural passou a ser concebido pela perspectiva da modernização ecológica (Buttel, 2000; Catton e Dunlap, 1980). Essa vertente considera a perspectiva da sustentabilidade, ou seja, a possibilidade de associar crescimento econômico e proteção ambiental, como base na reestruturação das políticas econômicas em face das novas posturas ecológicas, com a ambientalização das práticas agrícolas campesinas.

O programa do $\mathrm{PCO}^{35}$ apresenta um diagnóstico sobre a crise capitalista, que resultou na ruína da pequena propriedade, na transformação do produtor em trabalhador assalariado e na monopolização dos meios de produção por um número reduzido de grandes proprietários:

A esta monopolização está ligada a eliminação da produção artesanal, a transformação da ferramenta em maquinaria, a automatização industrial e a formação do mercado mundial. O capitalismo representou um extraordinário

${ }^{35}$ Disponível em: <http://www.pco.org.br/pco/programa.htm>. Acesso em: 5 set. 2014. 
desenvolvimento das forças produtivas do trabalho humano, mas os benefícios deste progresso são totalmente usurpados pelos capitalistas e os grandes proprietários, o que para a classe operária e os setores oprimidos intermediários significa o aumento da insegurança de sua existência, da miséria social, da exploração e da sua de gradação (PCO, Programa partidário, s.p.).

O PSTU adota discurso similar, ao apontar o combate à destruição ambiental como estratégia de "luta contra o capitalismo". No website da legenda ${ }^{36}$ há um manifesto de cunho socialista, cujo título é "Combater a destruição ambiental é lutar contra o capitalismo" ${ }^{17}$. Segundo o manifesto,

a submissão do Brasil à economia capitalista está por trás da destruição do meio ambiente. A demanda cada vez maior por matérias-primas provocou a expansão da exploração da mineração e das monoculturas de soja, cana de açúcar, eucaliptos etc. O agronegócio avançou por todo o Cerrado e agora se expande para a Amazônia. Esse avanço fez com que o Brasil se tornasse o maior consumidor de agrotóxicos do mundo. Por aqui, é permitida a utilização até dos agrotóxicos que foram banidos em outros países. 0 resultado é a contaminação dos alimentos, da água e do solo por substâncias químicas maléficas à saúde humana (PSTU, Programa partidário, s.p.).

Outro trecho do manifesto aponta a incompatibilidade entre a lógica capitalista e os princípios ecológicos:

O uso irracional dos recursos naturais tem provocado a destruição do meio ambiente em proporções gigantescas. Voltada para os lucros imediatos, a exploração capitalista se move por uma lógica de curto prazo, o que é incompatível com o tempo de recuperação da natureza. 0 resultado tem sido a contaminação do solo, do ar e da água, a devastação das florestas tropicais, o aumento da temperatura do planeta e o esgotamento dos recursos necessários à sobrevivência humana (PSTU, Programa partidário, s.p.).

O programa partidário do $\mathrm{PCB}^{38}$ é sucinto quanto à questão e limita-se a uma breve crítica ao modelo de desenvolvimento capitalista,

que ameaça não apenas os trabalhadores, mas a própria vida humana, numa irracional exploração dos recursos naturais e sociais que são

\footnotetext{
${ }^{36}$ Disponível em: <http://www.pstu.org.br/node/20868>. Acesso em: 5 set. 2014.

${ }^{37}$ A íntegra do manifesto também foi publicada no jornal do PSTU, intitulado Opinião Socialista, no 482.

38 Disponível em: <http://www.pcb.org.br/portal/docs/historia1.pdf>. Acesso em: 5 set. 2014.
} 
necessários à reprodução da vida. ( $P C B, A$ formação histórica do capitalismo, p. 1).

A posição ideológica dos partidos de orientação comunista e socialista apresenta algumas convergências com a análise de Sainteny (1994) e Duverger (2011). Além disso, reflete parte das críticas fundamentadas na concepção de ecologia política, segundo a qual o discurso da sustentabilidade mudou o foco da exploração capitalista do homem para a natureza (Latour, 1994; 1999). A crítica feita pelos partidos, nessa perspectiva, "torna-se um recurso, uma competência entre outras, a gramática de nossas indignações" (Latour, 1994, p. 49). Uma limitação dessa vertente, na visão do mesmo autor, é a abordagem totalizante, pois esses críticos tratam a natureza e o sistema político como uma totalidade. Por essa razão, a ecologia política perdeu força e tornou-se marginal, "porque não compreendeu ainda nem sua política, nem sua ecologia" (Latour, 1999, p. 48).

Esses partidos conjugam sustentabilidade econômica, social e ecológica, mas apenas no plano retórico, pois não apresentam propostas específicas de governança ambiental. Em suma, os programas partidários comunistas assemelham-se mais a manifestos anticapitalistas do que a programa de governança ambiental propriamente dito. Entretanto, o manifesto é coerente com a identidade e a trajetória dessas agremiações, cujo objetivo primordial é marcar posição no contexto da concorrência partidária e não propor governança efetivamente, visto que não apresentam chances de eleger candidatos para cargos executivos, como presidente da República ou governadores.

\section{Partidos desenvolvimentistas: sustentabilidade econômica}

Quatro legendas apresentam em comum a defesa de um novo modelo de desenvolvimento socioeconômico, com bases sustentáveis, mas de modo a garantir o progresso econômico: PSB, PMDB, PT, PRB e PSB.

O programa do PSB é o mais abrangente e mais detalhado no eixo temático do desenvolvimento econômico. O texto contempla "uma agenda de mudanças profundas na forma de fazer política e no modelo de desenvolvimento social e econômico". Isso implica "um modelo de desenvolvimento profundamente comprometido com a democracia e com a sustentabilidade", além de "planejar uma transição estratégica para o desenvolvimento de novo tipo". Conforme o texto, é necessário "posicionar o Brasil na realidade global marcada por crise ambiental". Para a legenda, é mister aproveitar a privilegiada condição do Brasil, como país detentor de reconhecido patrimônio natural e diversidade cultural:

O Brasil abriga parte significativa da biodiversidade e da água doce existente no planeta, grande extensão de terras cultiváveis, diversidade étnicocultural, bem como uma rica variedade de formações naturais cujo papel é 
fundamental no equilíbrio climático continental e global. No entanto, as instituições políticas e os sucessivos governos, nas últimas décadas, não têm absorvido e dado relevo ao papel crucial da sustentabilidade no processo de desenvolvimento (PSB, Programa partidário, p. 14).

Segundo o programa do PSB, a política ambiental terá como principal diretriz o desenvolvimento econômico sustentável, discutindo com a sociedade, parlamento e entes federados um conjunto de metas socioambientais de curto, médio e longo prazos para o país. "Essas metas deverão incorporar os limites ecossistêmicos, de um lado, e o potencial estratégico da nossa biodiversidade e dos recursos naturais renováveis" ( $p$. 16).

Em função da candidatura de Marina Silva à presidência da República, o programa da legenda apresenta um conjunto amplo de propostas para a governança ambiental, envolvendo diversas áreas, como economia verde, energia, mobilidade urbana, política industrial e economia do conhecimento e da inovação. Cabe ressaltar que boa parte do texto assumido pelo PSB foi incorporado a partir das propostas de Marina Silva ${ }^{39}$, após o acordo que resultou no apoio da Rede Sustentabilidade à candidatura de Eduardo Campos. As propostas apresentadas aproximam-se do que Giddens (2010) denomina de convergência política, ou seja, combinação de políticas de diferentes áreas, como energia, inovação tecnológica, planejamento econômico e outras, com o mesmo propósito comum de mitigar os problemas ambientais e assegurar qualidade de vida aos cidadãos.

Trata-se do plano mais abrangente, que arrola o maior número de setores e com propostas específicas para cada área. Contempla aspectos ignorados pela maioria dos demais partidos como a economia criativa, inovação, negócios sociais e economia solidária. Aproxima-se muito da concepção apresentada pelo PV, em termos de ecologia sistêmica, e alberga as variadas dimensões da sustentabilidade, com a proposta de ações convergentes, integradas e coordenadas.

O programa do PSB é focado na lógica da modernização ecológica (Buttel, 2000; Catton e Dunlap, 1980). Segundo essa perspectiva, a sustentabilidade consiste em associar crescimento econômico e proteção ambiental, como base na reestruturação das políticas econômicas em face das novas posturas ambientais. A preservação funciona como guia para orientar a economia, o que inclui, necessariamente, elementos da infraestrutura produtiva do meio rural, os arranjos produtivos locais, a agricultura familiar e as comunidades tradicionais. Trata-se de uma visão em que há uma convergência das forças econômicas, de modo a reestruturar as políticas econômicas, a fim de torná-las mais defensáveis em termos ambientais (Giddens, 2010). Enquadra-se na perspectiva da sustentabilidade econômica ou economia verde (May, Lustosa e Vinha,

\footnotetext{
${ }^{39}$ Conferir em: <http://www.marinasilva.org.br/diretrizes_governo/governo/economiasustentavelv2.php>. Acesso em: 5 set. 2014.
} 
2003). Segundo essa visão, a sustentabilidade ambiental constitui posicionamento estratégico no desenvolvimento nacional e na competitividade internacional. Isso explica a ênfase em setores essenciais da economia verde.

No caso do PMDB, o programa partidário ${ }^{40}$ propõe "um novo modelo de desenvolvimento", com base em uma política de desenvolvimento autossustentado "centrada na ideia de que o desemprego é, hoje, o nosso fator mais grave de poluição e degradação ambiental" (PMDB, Programa partidário, sem paginação). O foco da proposta está na revisão das políticas para os setores agrícola, hídrico, energético, industrial e de ciência e tecnologia. Com isso, segundo o programa do PMDB, seria possível maior inserção competitiva do Brasil na economia internacional.

No programa do $\mathrm{PT}^{41}$, há um capítulo intitulado "Sustentabilidade", cujo foco é a "construção de um modelo de desenvolvimento que contemple os aspectos democráticos, econômicos, sociais e ambientais". O objetivo desse modelo é promover crescimento econômico, erradicação da pobreza, preservação do meio ambiente e ampliação da democracia. Segundo o texto,

São exemplos internos, que dão suporte a nossas posições internacionais, nosso empenho contra o desmatamento, o incremento de nossa matriz energética renovável, nossas práticas e políticas sustentáveis na agricultura e na indústria. Não precisa existir contradição entre crescer, incluir, proteger e conservar (PT, Programa de Governo, sem paginação, grifos acrescentados).

O programa do PT limita-se ao que foi transcrito acima, sem detalhar as propostas para o setor. Infere-se, contudo, pelo teor das proposições, que serão priorizadas as áreas de agricultura, indústria e energia. Apesar de mencionar elementos típicos da sustentabilidade social e ecológica, como erradicação da pobreza, preservação do meio ambiente e ampliação da democracia, esses termos ficam sem detalhamento no texto. Funcionam mais como ornamento do que como proposta política no sentido estrito. O Estado também aparece como garantidor das diretrizes e princípios de desenvolvimento.

O foco do documento do PT é, visivelmente, no crescimento econômico, o que reflete uma preocupação sobre as condições de governabilidade, visto que se trata de um partido que elegeu o titular do Poder Executivo federal e uma expressiva bancada no Congresso Nacional. A ênfase nos setores agrícola e industrial justifica-se pelo peso que ambos exercem na economia brasileira, com $23 \%$ e $24,9 \%$ do Produto Interno Bruto (PIB), respectivamente. Considerando o ano de 2013, conforme levantamento do

\footnotetext{
${ }^{40}$ Disponível em: <http://pmdb.org.br/institucional/programa-partidario/>. Acesso em: 5 set. 2014.

41 Disponível em: <https://www.pt.org.br/wp-content/uploads/2014/05/DIRETRIZES-PROGRAMA-DEGOVERNO-DILMA-PRESIDENTE-20141.pdf>. Acesso em: 5 set. 2014.
} 
Instituto Brasileiro de Geografia e Estatística (IBGE) ${ }^{42}$, o somatório dos dois segmentos totaliza 47,9\%, ou seja, quase a metade do PIB. O componente energia é indispensável para o crescimento econômico, especialmente no campo da indústria.

O programa do PRB contempla a agenda ambiental no âmbito de seus princípios básicos republicanos ${ }^{43}$, no plano da política econômica:

A política econômica deve visar ao desenvolvimento econômico e social, mediante a utilização plena e soberana dos recursos humanos e materiais da sociedade, dentro de critérios responsáveis em relação ao meio ambiente (PRB, Programa partidário, s.p.).

O partido atribui ao Estado o papel de promover o desenvolvimento socioeconômico autossustentado, seguindo critérios razoáveis de responsabilidade ambiental. O texto, porém, não apresenta o teor dos critérios mencionados.

\section{Partidos ecologistas sistêmicos: convergência sustentável}

Os dois partidos de orientação tipicamente ecológica enquadram-se nesse eixo temático: PV e PEN. Apesar de apresentarem programas específicos, ambos convergem para alguns aspectos gerais do debate ambiental. Na abertura do texto que institui 0 programa partidário ${ }^{4}$, o PV é definido como "um instrumento da ecologia política", em articulação com os demais partidos e com os movimentos verdes de outros países, o que reitera aspectos de sua história no que se refere aos vínculos com os movimentos ecológicos europeus. Em termos mais amplos, a proposta da legenda é "desenvolver uma estratégia conjunta e uma ação coordenada em favor do desarmamento, da desnuclearização, do ecodesenvolvimento, da solução negociada dos conflitos e do respeito às liberdades democráticas, justiça social e direitos humanos".

O programa mostra conexão do PV com o movimento ecologista, as comunidades locais e os poderes institucionais:

O PV luta pelo fortalecimento do movimento ecologista e pela realização das suas propostas. Funciona como um canal de ação política, no campo institucional, para servir o ambientalismo, sem pretensões hegemônicas ou instrumentalizantes. O PV participa, através dos seus militantes, dos movimentos sociais, culturais e das organizações não governamentais. O PV deve organizar-se junto às comunidades locais, obter o poder através dos diversos níveis do Legislativo e Executivo, para a execução do programa

\footnotetext{
${ }^{42}$ Dados disponíveis em: <http://www.ibge.gov.br/home/estatistica/pesquisas/indicadores.php>. Acesso em: 5 set. 2014.

${ }^{43}$ Disponível em: <http://www.prb10.org.br/o-partido-republicado-brasileiro/programa/>. Acesso em: 5 set. 2014.

${ }^{44}$ Disponível em: <http://pv.org.br/opartido/programa/>. Acesso em: 5 set. 2014.
} 
verde no plano local, regional e nacional (Partido Verde, Programa partidário, s.p.).

O texto reitera ainda a estreita relação entre a questão ambiental e a questão social. "Os problemas tanto sociais como ambientais devem ser tratados numa perspectiva integrada e sistêmica para realmente terem efeito sobre a qualidade de vida da população". Isso significa que

a simples preocupação conservacionista da natureza, sem uma sensibilidade social aliada à incapacidade de apontar modelos de desenvolvimento sustentável só pode agravar a miséria e abrir caminho a uma devastação ambiental ainda maior no futuro. Os verdes propugnam o desenvolvimento sustentável como caminho para combater a miséria e o desperdício. Isso significa gerar trabalho e empregos de forma intensiva na preservação e recuperação ambiental e desenvolver novos setores da economia baseados em tecnologias limpas (Partido Verde, Programa partidário, s.p.).

O caminho apontado pelo PV para a superação das contradições implicadas na agenda socioambiental é a educação para a cidadania e o ecodesenvolvimento:

O principal obstáculo a um desenvolvimento sustentado e a uma democracia plena no país é o cada vez mais baixo nível educacional e cultural das sucessivas gerações que passam pelo ou ao largo do sistema educacional vigente. A degradação do sistema educacional, sua incapacidade de formar cidadãos e também servir de base para uma valorização profissional adequada prejudica notavelmente a consolidação de uma sociedade solidária e de uma economia capaz de criar o máximo de valor agregado, o que depende de mão de obra qualificada (Partido Verde, Programa partidário, s.p.).

O PV apresenta ainda propostas setorizadas por áreas como energia renovável, economia verde, poder local, Agenda 21, qualidade de vida, saúde, reforma agrária, combate à fome e à pobreza.

O programa do PEN, por sua vez, é similar a um manifesto, embora seja denominado "Proposta Ecológica"45,

o Partido Ecológico Nacional nasce para cumprir uma missão. Para preencher um espaço vazio no cenário político brasileiro. Embora o viés ambiental, felizmente, venha aos poucos encontrando espaço no programa políticopartidário de algumas agremiações, denota-se que, no mais das vezes, o

45 Disponível em: <http://www.pen51.org.br/mandamentos.php\#.U71Oc_IdWLE>. Acesso em: 5 set. 2014. 
que se percebe são iniciativas isoladas, ações pontuais e nenhum processo de continuidade. Mesmo naquelas criadas para tutelar o meio ambiente 0 ideal cedeu aos interesses políticos, enfraquecendo as bases $\mathrm{e}$ empobrecendo o louvável ideal que um dia marcaram suas lutas (PEN, Programa partidário, s.p.).

O PV e o PEN convergem em termos de ecologia sistêmica e albergam variadas dimensões da sustentabilidade, com propostas de ações integradas e coordenadas. Uma diferença entre ambos é o predomínio de uma retórica de cunho mais utópico no documento do PV e de um programa de teor mais pragmático e específico no caso do PEN. Apesar de se tratar de propostas de governança difíceis de serem viabilizadas em função da complexidade e da necessidade de alianças políticas, as proposições do PEN concentram-se em três áreas basilares para a construção de uma nova cultura ambiental: legislação ambiental, novo modelo de desenvolvimento econômico e definição de políticas de planejamento ambiental para setores específicos, como proteção de matas ciliares, coleta de lixo e energias limpas.

\section{Conclusões}

A análise mostra que há um expressivo interesse dos partidos políticos no que se refere à inclusão de temas ambientais em seus websites e nos programas partidários. 0 mapeamento permitido pela pesquisa documental revela que dos 32 partidos registrados na Justiça Eleitoral até o momento de conclusão da pesquisa ${ }^{46}, 20$ assumiam sua adesão ao discurso ecológico. O dado mais relevante é o predomínio da adesão explícita à agenda verde, por meio de um capítulo ou tópico do programa partidário inteiramente dedicado ao assunto. São 17 partidos que adotam essa postura. Esses dados são relevantes para compreender as dinâmicas contemporâneas de atuação das legendas, seja sob a perspectiva das estratégias de informação digital, seja sob o ângulo do acolhimento de novas causas, especialmente aquelas oriundas inicialmente de movimentos sociais, como é o caso do ambientalismo. Trata-se, portanto, de uma perspectiva relevante para o campo da sociologia dos partidos políticos, uma vez que oferece pistas para o aprofundamento da análise da relação entre partidos e movimentos sociais, além das dinâmicas de concorrência entre as próprias legendas na arena eleitoral, um dos eixos dos estudos atuais sobre a organização dos partidos (Amaral, 2013).

Outra conclusão relevante diz respeito à cartografia dos principais temas enfatizados nos programas partidários, no que se refere à questão ambiental. São quatro os grandes eixos temáticos mapeados a partir da análise dos documentos, os quais

\footnotetext{
${ }^{46}$ Em setembro de 2015 foram registrados três novos partidos na Justiça Eleitoral: o Partido Novo (PN), o Partido da Mulher Brasileira (PMB) e a Rede Sustentabilidade. Exceto o último, os demais ainda não apresentaram propostas específicas para a área ambiental.
} 
correspondem aos perfis partidários identificados durante a análise. O que chama atenção no bloco dos partidos desenvolvimentistas é que se destacam legendas de grande porte, como o PMDB, o PT e o PSB, além de reunir uma maioria de orientação ideológica denominada de centro e de centro-esquerda. Em geral, são partidos comprometidos com pautas de governança ecológica atrelada ao progresso econômico e ao desenvolvimento de setores considerados estratégicos para a economia brasileira, a exemplo da agropecuária, indústria, energia, ciência e tecnologia. Trata-se de um discurso que visa a promover emprego e inclusão social pela via do "progresso sustentável", mas as políticas de proteção da natureza ficam em segundo plano. Diante disso, cabe indagar: O que efetivamente esses partidos entendem por desenvolvimento sustentável? Qual a relação entre ambientalismo e identidade partidária? Quais os vínculos desses partidos com os movimentos sociais de orientação ecológica? São questões cujo aprofundamento carece de mais pesquisas e de um acompanhamento continuado das propostas inseridas em seus programas partidários.

Os críticos ao capitalismo são todos de esquerda e apresentam uma visão utópica sobre a relação entre ecologia e sistema econômico. O que há em comum entre esses partidos é a matriz ideológica de orientação socialista, tal qual revelam as análises de Sainteny (1994) e Duverger (2011) sobre o Partido Socialista francês. No caso brasileiro, as legendas analisadas chegam a propor um modelo estatal capaz de remodelar o sistema produtivo capitalista, considerado mola de uma economia predatória, que explora irracionalmente a natureza e causa o desequilíbrio dos ecossistemas. Os conservacionistas defendem maior centralidade das políticas de preservação, a partir de uma visão biocêntrica de patrimonialização da natureza, segundo a qual o Estado deve ampliar o número de unidades de conservação e manter algumas áreas florestais intocadas. Esses partidos dão ressonância às ideias de movimentos de base conservacionista, cujos líderes foram cientistas e naturalistas defensores da preservação de paisagens, recursos naturais e espécies animais e vegetais (Pádua, 1990; Oliveira, 2008). Os ecologistas sistêmicos pregam transformações sociopolíticas e culturais amplas, associando democracia e cidadania ecológica. As pautas defendidas pelos programas partidários desse segmento são amplas, incluindo temas como cultura de paz, desarmamento, igualdade e justiça social, direitos humanos, desenvolvimento regional e economia solidária.

As dimensões da sustentabilidade são acionadas de modo distinto, com maior ênfase na sustentabilidade econômica ou em outras dimensões, como social, cultural ou ecológica, conforme o perfil partidário. Os partidos desenvolvimentistas, por exemplo, acentuam a sustentabilidade econômica, enquanto os conservacionistas priorizam a sustentabilidade ecológica. Os sistêmicos, por sua vez, enfatizam a sustentabilidade cultural e social, conforme foi demonstrado no tópico sobre a análise desses aspectos.

Esses dados são relevantes para a compreensão dos sentidos atribuídos à agenda socioambiental pelas diferentes legendas. Tais sentidos se revelam com mais intensidade 
na cartografia dos termos-chave mais citados nos programas partidários. Desenvolvimento é vinculado principalmente a termos como prosperidade econômica, sustentabilidade e energias renováveis. As críticas ao sistema capitalista aparecem nos programas dos partidos de esquerda, como PCdoB, PCB, PDT, PSOL, PSTU e PCO. Ao ser incorporado aos programas partidários, o discurso crítico assume a forma de manifesto contra o sistema industrial vigente, associado aos seguintes termos: poluição, degradação, devastação, contaminação do solo e esgotamento dos recursos naturais. As legendas que assumem e defendem um viés conservacionista são PP, PSDC, PSD, PTB, PPS e DEM, cujos termos mais citados são preservação, conservação, proteção da natureza, responsabilidade ambiental.

Os partidos que são associados diretamente à causa ecológica, como o PV e o PEN, assumem um discurso vinculado ao debate sobre ecologia política, ecologia urbana e cidadania ecológica. São termos muito amplos, cujos sentidos são depreendidos a partir dos termos-chave que aparecem com mais ênfase nos respectivos programas partidários, tais como: ecodesenvolvimento, movimentos ecológicos, qualidade de vida, preservação e recuperação ambiental, tecnologias limpas, legislação ambiental, unidades de conservação, reciclagem e coleta seletiva.

A diversidade de ambientalismos presente nos programas partidários analisados contribui para a compreensão de como as legendas tentam atrair a atenção pública para suas propostas políticas na área ambiental, considerando que as diversas agremiações representam a pluralidade ideológica da política (Peirano, 2011). As diferentes agremiações correspondem às distintas visões e divisões do mercado político e dos movimentos sociais e ecológicos. Portanto, oferecem, no âmbito do sistema de representação democrático liberal, distintas possibilidades de adesão política dos eleitores à agenda verde, uma agenda igualmente multifacetada e com perfis eleitorais variados. Essa perspectiva é coerente com os estudos que apontam para uma tendência de requalificação dos partidos, o que implica redefinições, atualização e adaptação aos novos contextos. Isso não implicaria, portanto, enfraquecimento ou declínio das legendas, mas uma redefinição de suas funções e de seus modos de atuação e operação política (Amaral, 2013). Caberiam, entretanto, análises mais pormenorizadas para aprofundar questões decorrentes dessas dinâmicas de requalificação dos partidos e de adaptação às novas agendas e circunstâncias políticas. Afinal, até que ponto a adesão das legendas à agenda verde pode ser considerada uma estratégia eficaz nesse sentido? Quais os impactos eleitorais da incorporação dos discursos ecológicos pelos programas partidários no contexto recente? Como os eleitores respondem a essas estratégias das legendas? Diante das crises e metamorfoses da democracia representativa (Urbinati, 2013b), como a adesão à agenda verde pode (re)conectar as legendas aos movimentos sociais e a segmentos eleitorais com distintas visões ecológicas? Até que ponto o uso da internet como instrumento de visibilidade das propostas partidárias pode contribuir nesse processo? 
Em todos os perfis, com suas diversidades de visões de ambientalismo, de sustentabilidade e de governança ecológica, o Estado é visto pelos partidos como um ator que deve ser instrumentalizado para a execução das propostas ecológicas, segundo a concepção de Giddens (2010), no que se refere ao Estado assegurador. A centralidade do papel do Estado é um aspecto que chama atenção nas propostas constantes nos programas partidários. O Estado aparece como guardião das políticas de preservação, indutor da sustentabilidade e de uma nova cultura ambiental, além de agente de construção de uma nova ordem econômica. O Estado é legitimado pelo discurso das legendas como ator-chave no processo de formulação e de implementação das políticas públicas setoriais na área ambiental. Um exemplo disso são as políticas climáticas, as leis para proteção das florestas e dos recursos hídricos, além de setores como energias limpas, combate à poluição, entre outros, que constituem o cerne da agenda ecológica global. Em suma, os partidos se apresentam como caixa de ressonância da sociedade civil, como intérpretes e tradutores das novas causas oriundas dos movimentos sociais e ecológicos, mas atribuem ao Estado a função de transformar essas causas em políticas públicas e assegurar sua execução.

As ideias de governança ambiental apresentadas pelos partidos vinculam-se às três principais funções exercidas pelas legendas: sua atuação na arena eleitoral, sua atuação institucional e sua relação com os governos (Key, 1964; Veiga, 2007; Amaral, 2013). A inclusão de temas da agenda verde nos programas partidários constitui uma estratégia de aproximação com o eleitorado, uma vez que as questões ecológicas passaram a permear variadas esferas da sociedade e tornaram-se foco das preocupações públicas e das campanhas eleitorais, a exemplo do Partido Socialista francês (Sainteny, 1994; Duverger, 2011). Do mesmo modo, os partidos tentam reafirmar sua atuação institucional, ao incorporar em seu discurso a agenda da sustentabilidade, uma abordagem com ampla ressonância na sociedade, já que o discurso ecológico passou a orientar práticas e relações sociais nas últimas décadas (Barros, 2013). As legendas reforçam ainda sua função de mediação política, ao se apresentarem como agentes habilitados para propor e negociar políticas públicas para o desenvolvimento sustentável.

Caberia questionar, contudo, como a inserção de temáticas ecológicas nos programas partidários pode potencializar ou fortalecer a função de mediação política dos partidos (Weber, 1999), especialmente na arena parlamentar. Entendida como um processo político dinâmico e complexo, a mediação está relacionada com a articulação entre identidade e instrumentalidade exercida pelos partidos (Reis, 2010). Isso implica um conjunto de lutas simbólicas para assegurar um campo de exercício de influência e poder, especialmente em termos de política de visibilidade e de reputação partidária. Nesse sentido, a incorporação de aspectos temáticos associados à agenda ecológica pode ser interpretada também como estratégia de publicidade política, ou seja, uma forma de propaganda das legendas a fim de consolidar seu poder discursivo na esfera da concorrência eleitoral. 
A baixa consistência de alguns programas mostra que existe uma tendência dos partidos de aderir à agenda verde de modo menos enfático e sistemático. Apesar disso, abraçar as causas verdes, mesmo que não seja uma prioridade do partido, torna-se uma estratégia para aumentar a visibilidade na arena eleitoral, talvez por um imperativo político contextual e pela própria concorrência partidária. A constatação de que um determinado candidato ou partido inclui propostas de governança ambiental, instiga os demais a fazerem o mesmo. A competição conduz a padrões similares, com ênfase em alguns focos que se repetem, como a própria ideia de sustentabilidade, com o objetivo de adotar estratégias focadas em articular conexões com os mesmos públicos do mercado eleitoral (Barros, Bernardes e Rodrigues, 2014). Trata-se, portanto, de uma escolha estratégica para responder a uma demanda contextual que adquiriu relevância inclusive do ponto de vista eleitoral, como mostram os estudos de Sainteny (1994) e Duverger (2011). A inclusão de temáticas ecológicas no programa partidário pode ser interpretada, portanto, como estratégia para fortalecer a reputação pública das legendas.

Cabe reiterar que a inserção das pautas ambientais na agenda e no programa dos partidos políticos deve ser compreendida como um fenômeno social e culturalmente construído, ou seja, resultante das relações entre os diferentes sujeitos e atores sociais e políticos, representados por múltiplos polos de interesse, tais como o Estado, a sociedade civil, os movimentos sociais e a comunidade científica, como foi ressaltado na primeira parte do texto, com base nas ideias de autores como Bobbio (1992), Castells (1999), Giddens (2010), Habermas (1995) e Hobsbawn (1995). Ao deixar de ser uma questão outsider e se tornar uma questão estabelecida (Giddens, 2010), a agenda verde foi incorporada gradativamente ao discurso político partidário como forma de assegurar espaço na arena eleitoral. Trata-se de uma tentativa de construir uma narrativa política associada à sustentabilidade, a fim de conquistar segmentos do eleitorado que se identificam com a temática.

Por fim, é oportuno salientar que o estudo aqui exposto, por se tratar de uma pesquisa documental, de natureza exploratória e descritiva, apresenta algumas limitações intrínsecas ao seu escopo e ao seu método, o que impede um aprofundamento maior no que se refere a explicações mais densas sobre a relação entre os programas partidários e os posicionamentos das legendas na disputas eleitorais quanto à agenda ambiental. Como alternativa possível para aprofundar tais aspectos, um caminho viável seria analisar o peso das temáticas ambientais em contextos eleitorais, tanto no que se refere a eleições presidenciais como a eleições legislativas, a exemplo do estudo referencial de Sainteny (1994) sobre a atuação do Partido Socialista francês. Tal escopo analítico, contudo, ficará para outro artigo, já em andamento.

Antonio Teixeira de Barros - Doutor em Sociologia pela Universidade de Brasília. Docente e pesquisador do Programa de Mestrado em Ciência Política do Centro de Formação da Câmara dos Deputados (Cefor). E-mail: <antonibarros@gmail.com>. 


\section{Referências bibliográficas}

Albuquerque, A.; Martins, A. F. "Apontamentos para um modelo de análise dos partidos na Web". In: Anais do XIX Encontro da Compós. Rio de Janeiro, 2010.

Almeida, J.; PremebidA, A. "Histórico, relevância e explorações ontológicas da questão ambiental". Sociologias, vol. 16, n 35, p. 14-33, 2014.

Alonso, A.; COSTA, V. "Ciências Sociais e meio ambiente no Brasil: um balanço bibliográfico". BIB Revista Brasileira de Informações Bibliográficas em Ciências Sociais, nº 53, p. 35-78, $1^{\circ}$ sem. 2002.

AmARAL, O. E. "O que sabemos sobre a organização dos partidos políticos: uma avaliação de 100 anos de literatura". Debates, Porto Alegre, vol. 7, n² 2, p. 11-32, maio-ago. 2013.

BAQUeRo, M. A vulnerabilidade dos partidos políticos e a crise da democracia na América Latina. Porto Alegre: Ed. Universidade/UFRGS, 2000.

BArros, A. T. "Dimensão filosófica e política do pensamento ambiental contemporâneo". Veritas, Porto Alegre, vol. 57, n 1, p. 92-111, jan.-abr. 2012.

" "A visibilidade ambiental em perspectiva sociológica: estudo comparado Brasil-Portugal". Sociologias, vol. 15, p. 318-345, 2013.

Barros, A. T.; Bernardes, C. B.; Rodrigues, M. R. "Palanques virtuais: o uso de websites pelos partidos políticos brasileiros". In: Anais do $38^{\circ}$ Encontro Anual da Anpocs. Caxambu, 2014.

Barros, A. T.; SousA, J. P. Jornalismo e ambiente. Porto: Edições Universidade Fernando Pessoa, 2010.

BAumAn, Z. Em busca da política. Rio de Janeiro: Zahar, 2000.

BECK, U.; GIDdENS, A. ; LASH, S. Modernização reflexiva: política, tradição e estética na ordem social moderna. São Paulo: Editora da Unesp, 1994.

BlAnChARD, G. "O uso da internet a serviço do partido". Líbero. São Paulo, vol. 9, n 18, p. 9-17, dez. 2006.

Boвbio, N. A era dos direitos. Rio de Janeiro: Campus, 1992.

BoKTIN, D. B. Qual ecologia para o século XXI?. In: BARRÈRE, M. (org.). Terra, patrimônio comum: a ciência a serviço do meio ambiente e do desenvolvimento. São Paulo: Nobel, p. 15-26, 1992.

Borraz, O. "O surgimento das questões de risco". Sociologias, vol. 16, n 35, p. 106-137, 2014.

Bourdieu, P. O poder simbólico. Lisboa: Difel, 1989.

BRAGA, S. S.; FRANÇA, A. S. T.; NicolÁS, M. A . "Os partidos políticos brasileiros e a internet: uma avaliação dos websites dos partidos políticos do Brasil". Revista de Sociologia e Política, vol. 17, nº 34, p. 183-208, 2009.

ButTeL, F. H. Ecological modernization as social theory. Geoforum: Oxford, p. 57-65, 2000.

CARREIRÃo, Y. S. "O sistema partidário brasileiro: um balanço de tendências recentes". In: Anais do $36^{\circ}$ Encontro Anual da Anpocs, Águas de Lindoia, 2012.

CARREIRÃo, Y. S.; Kinzo, M. G. "Partidos políticos, preferência partidária e decisão eleitoral no Brasil (1989-2002)". Dados, vol. 47, n 1, p. 131-168, 2004. 
POLÍTICA PARTIDÁRIA E MEIO AMBIENTE: A ADESÃO DOS PARTIDOS POLÍTICOS BRASILEIROS À AGENDA VERDE

Carvalho, I. C. M. "A ecodemocracia". PG, vol. 69, p. 10-14, maio-jun. 1991.

. "As transformações na esfera pública e a ação ecológica: educação e política em tempos de crise da modernidade". Revista Brasileira de Educação, vol. 11, n 32, p. 308-315, maio-ago. 2006.

Castells, M. O poder da identidade. Rio de Janeiro: Paz e Terra, 1999.

. A galáxia da internet. Rio de Janeiro: Zahar, 2003.

CATTON, W. R.; DUNLAP, R. E. "A new ecological paradigm for post-exuberant sociology". American Behavioral Scientist, vol. 24, n 1, p. 15-47, set.-out. 1980.

Dalton, R.; WATtenberg, M. Parties without partisans: political change in advanced industrial democracies. Oxford: Oxford University Press, 2000.

Duverger, T. Le parti socialiste et l'écologie - 1968-2011. Paris: Jean Jaurés Fondation, 2011.

Figueiredo, E. Angústia ecológica e o futuro. Lisboa: Gradiva, 1993.

FLeURY, L. C.; ALMEIDA, J.; PREMEBIDA, A. "O ambiente como questão sociológica: conflitos ambientais em perspectiva". Sociologias, vol. 16, n 35, p. 34-82, 2014.

GidDens, A. A política da mudança climática. Rio de Janeiro: Zahar, 2010.

Gomes, W. Transformação da política na era da comunicação. São Paulo: Paulus, 2004.

GUIMARÃES, R. P. Ecopolitics in the third world: an institutional analysis of environmental management in Brazil. University of Connecticut, 1986.

HABERMAS, J. "O Estado-nação europeu frente aos desafios da globalização". Novos Estudos Cebrap, São Paulo, n 43, p. 87-101, 1995.

HARVEY, D. Condição pós-moderna. São Paulo: Loyola, 1992.

Hobsbawn, E. A era dos extremos. São Paulo: Companhia das Letras, 1995.

INGLeHART, R. "Post-materialism in an environment of insecurity". American Political Science Review, n०75, p. 880-900, December 1981.

JACKSON, N. "Political parties, the internet and the 2005 general election: third time lucky?". Internet Research, vol. 17, n³, p. 249-271, 2007.

KEY, V. O. Politics, parties and pressure groups. New York: Crowell, 1964.

LAFER, C. Discurso do chanceler brasileiro, Celso Lafer, na sessão de Debate Geral da Unced. In: BRASIL, MINISTÉRIO DAS RELAÇõES EXTERIORES. A Inserção internacional do Brasil: a gestão do ministro Celso Lafer no Itamaraty. Brasília: Ministério das Relações Exteriores, 1993.

LASH, S. Crítica de la información. Buenos Aires-Madrid: Amorrortu Editores, 2005.

LATOUR, B. Jamais fomos modernos. Rio de Janeiro: Editora 34, 1994. . Políticas da natureza: como fazer ciência na democracia. Bauru: Edusc, 2004.

LEFF, E. "Complexidade, racionalidade ambiental e diálogo de saberes". Educação \& Realidade, vol. 34, $\mathrm{n}^{\circ}$ 3, p. 17-24, set.-dez. 2009. 
LESTON-BANDEIRA, C. "Studying the relationship between Parliament and citizens". The Journal of Legislative Studies, vol. 18, n³-4, p. 265-274, September-December 2012.

LipovetSky, G. A era do vazio. Lisboa: Edições 70, 2013.

LUSTOSA, M. C. J. Industrialização, meio ambiente, inovação e competitividade. In: MAY, P. H.; LUSTOSA, M. C. J.; ViNHA, V. (orgs.). Economia do meio ambiente: teoria e prática. Rio de Janeiro: Campus, p. 155-172, 2003.

MAIA, R. Mídia e vida pública: modos de abordagem. In: MAIA, R.; CASTRO, M. C. P. S. (orgs.). Mídia, esfera pública e identidades coletivas. Belo Horizonte: Editora da UFMG, p. 11-46, 2006.

MAInWARING, S. P. Sistemas partidários em novas democracias: o caso do Brasil. Rio de Janeiro. Rio de Janeiro: FGV, 2001.

MANin, B. "As metamorfoses do governo representativo". Revista Brasileira de Ciências Sociais, vol. $10, n^{\circ} 29$, p. 5-34, out. 1995. 115-127, 2013.

"A democracia do público reconsiderada". Novos Estudos - Cebrap, São Paulo, n 97, p.

MARQUES, F. P. J. A. "Sobre a comunicação político-partidária na internet: um estudo dos informativos digitais do PT e do PSDB". Galáxia, n 10, p. 129-146, dez. 2005.

MAY, P. H.; LUStosA, M. C. J.; VinhA, V. Economia do meio ambiente: teoria e prática. Rio de Janeiro: Editora Campus, 2003.

Meneguello, R. Partidos conservadores no Brasil. São Paulo: Paz e Terra, 2000.

MoIses, J. A. "A desconfiança nas instituições democráticas". Opinião Pública, vol. 11, n 1, p. 33$63,2005$.

MORIN, E. Introducción al pensamento complejo. Barcelona: Gedisa, 1994.

Nicolas, M. A.; Bragatto, R. C.; Sampaio, R. C. "Internet and politics studies in Brazil: mapping the characteristics and disparities of the research field". Brazilian Political Science Review, vol. 7, $\mathrm{n}^{\circ}$ 2, p. 114-140, 2013.

NORRIS, P. "Preaching to the converted? Pluralism, participation and party websites". Party Politics, vol. $9, n^{\circ} 1$, p. $21-45,2003$.

Oliveira, S. "Ligado a evangélicos, Partido Ecológico Nacional cresce no Norte e no Nordeste". Rede Brasil Atual, 20 jul. 2012. Disponível em: <http://www.redebrasilatual.com.br/politica/2012/07/ligado-a-evangelicos-partido-ecologiconacional-cresce-no-norte-e-no-nordeste>. Acesso em: 3 set. 2015.

OliveirA, W. J. F. "Gênese e redefinições do militantismo ambientalista no Brasil". Dados, vol. 51, nº 3, p. 751-777, 2008.

Oppo, A. Partidos políticos. In: Bobbio, N.; Matteucci, N.; PAsquino, G. Dicionário de política. $5^{a}$ ed. Brasília: Editora da UnB, 2000, p. 898-905.

PÁDUA, J. A. Natureza e projeto nacional: as origens da ecologia política no Brasil. Rio de Janeiro: Iuperj, 1986.

PÁDUA, J. "Nascimento da política verde no Brasil: fatores exógenos e endógenos". In: PÁDUA, J. A., et al. (orgs.). Ecologia e política mundial. Rio de Janeiro: Vozes, 1990, p. 135-61.

Panebianco, A. Modelos de partido. Madrid: Alianza Editorial, 1990. 
Pasquino, G. Partitocracia. In: Bobbio, N.; MatTeucci, N.; PAsquino, G. Dicionário de política. 5 a ed. Brasília: Editora da UnB, 2000, p. 905-909.

Peirano, M. O dito e o feito. São Paulo: Relume-Dumará, 2011.

Pereira, F. B. "A estabilidade e a efetividade da preferência partidária no Brasil". Revista Brasileira de Ciência Política, n 13, p. 213-244, 2014.

ReIS, F. W. "Identidade política, desigualdade e partidos brasileiros". Novos Estudos - Cebrap, n 87, p. $61-75,2010$.

RibeIRo, G. L. Ambientalismo e desenvolvimento sustentado: nova ideologia/utopia do desenvolvimento. In: RiBEIRo, G. L. Cultura e política no mundo contemporâneo: paisagens e passagens. Brasília: Editora da UnB, 2000, p. 130-170.

Römmele, A. "Political parties, party communication and new information and communication technologies". Party Politics, London, vol. 9, n 1, p. 7-20, 2003.

SACHS, I. Estratégias de transição para o século XXI: desenvolvimento e meio ambiente. São Paulo: Nobel, 1993.

SAINTENY, G. "Le parti socialiste face à l'écologisme. De l'exclusion d'un enjeu aux tentatives de subordination d'un intrus". Revue Française de Science Politique, vol. 44, n 3, p. 424-461, 1994.

SANTOS, B. S. Pela mão de Alice: o social e o político na pós-modernidade. 13a ed. São Paulo: Cortez, 2010.

SANTOS, F. O poder Legislativo no presidencialismo de coalizão. Belo Horizonte/Rio de Janeiro: Editora UFMG/Iuperj, 2001.

TRECHSEL, A., et al. Evaluation of the use of new technologies in order to facilitate democracy in Europe: e-democratizating the parliaments and parties in Europe. Genebra: European University Institute, 2004.

URBInAti, N. "Crise e metamorfoses da democracia". Revista Brasileira de Ciências Sociais, São Paulo, vol. 28, n 82 , p. 5-16, 2013a. 85-105, 2013b.

"Da democracia dos partidos ao plebiscito da audience". Lua Nova, São Paulo, nº 89, p.

VeIGA, L. F. "Os partidos brasileiros na perspectiva dos eleitores". Opinião Pública, Campinas, vol. $13, n^{\circ} 2$, p. 340-365, 2007.

Viola, E. J. "O movimento ecológico no Brasil (1974-1986): do ambientalismo à ecopolítica". Revista Brasileira de Ciências Sociais, São Paulo, vol. 1, nº 3, 1987.

VIOLA, E. J.; LEIS, H. R. A evolução das políticas ambientais no Brasil, 1971-1991: do bissetorialismo preservacionista para o multissetorialismo orientado para o desenvolvimento sustentável. In: HOGAN, D. J.; VIEIRA, P. F. (orgs.). Dilemas socioambientais e desenvolvimento sustentável. Campinas: Editora da Unicamp, p. 73-102, 1992.

WEBER, M. Economia e sociedade. Brasília: Editora da UnB, 1999. 


\section{Programas partidários citados}

Partido do Movimento Democrático Brasileiro. Programa partidário. Disponível em: <http://pmdb.org.br/institucional/programa-partidario/>. Acesso em: 10 ago. 2014.

Partido Trabalhista Brasileiro. Disponível em:

<http://www.ptb.org.br/?page=ConteudoPage\&cod=325>. Acesso em: 10 ago. 2014.

Partido Socialista Brasileiro. Programa partidário. Disponível em:

<http://www.psb40.org.br/imprensa/programa.pdf>. Acesso em: 11 ago. 2014.

Partido dos Trabalhadores. Diretrizes partidárias. Disponível em: <https://www.pt.org.br/wpcontent/uploads/2014/05/DIRETRIZES-PROGRAMA-DE-GOVERNO-DILMA-PRESIDENTE-20141.pdf>. Acesso em: 12 ago. 2014.

Democratas. Princípios do Democratas. Disponível em: <http://www.dem.org.br/wpcontent/uploads/2011/01/Principios-do-Democratas.pdf>. Acesso em: 13 ago. 2014.

Partido Republicano Brasileiro. Programa partidário. Disponível em: <http://www.prb10.org.br/opartido-republicado-brasileiro/programa/>. Acesso em: 14 ago. 2014.

Partido Comunista do Brasil. Programa Socialista para o Brasil.

Disponível em: <http://www.pcdob.org.br/documento.php?id_documento_arquivo=1>. Acesso em: 15 ago. 2014.

Partido Comunista Brasileiro. A formação histórica do capitalismo. Disponível em: <http://www.pcb.org.br/portal/docs/historia1.pdf>. Acesso em: 16 ago. 2014.

Partido Democrático Trabalhista. Compromissos prioritários. Disponível em <http://www.pdt.org.br/index.php/pdt/programa/1-compromissos-prioritarios>. Acesso em: 17 ago. 2014.

Partido Socialismo e Liberdade. Programa partidário. Disponível em: <http://www.psol50.org.br/site/paginas/2/programa >. Acesso em: 18 ago. 2014.

Partido da Causa Operária. Programa partidário. Disponível em: <http://www.pco.org.br/pco/programa.htm>. Acesso em: 19 ago. 2014.

Partido Socialista dos Trabalhadores Unificado. Combater a destruição ambiental é lutar contra o capitalismo. Disponível em: <http://www.pstu.org.br/node/20868>. Acesso em: 20 ago. 2014.

Partido Progressista. Programa partidário. Disponível em: <http://www.pp.org.br/textos/453/27435/ProgramaPartidario/?sIT=119032>. Acesso em: 21 ago. 2014.

Partido Popular Socialista. Documentos. Disponível em: <http://www2.pps.org.br/2005/index.asp?portal=\&id_municipio=\&opcao=documentos\&id_categoria $=3 \&$ flag $=s>$. Acesso em: 22 ago. 2014.

Partido Social Democrata Cristão. Programa partidário. Disponível em:

<http://www.psdc.org.br/sobre-nos/programa/>. Acesso em: 23 ago. 2014.

Partido Social Democrático. Princípios e valores. Disponível em: <http://www.psd.org.br/principiose-valores/>. Disponível em: <http://pv.org.br/opartido/programa/>. Acesso em: 24 ago. 2014.

Partido Ecológico Nacional. Os 10 mandamentos para um crescimento sustentável. Disponível em: <http://www.pen51.org.br/mandamentos.php\#.U71Oc_ldWLE>. Acesso em: 25 ago. 2014. 
Partido Solidariedade. Disponível em: <http://www.solidariedade77.org.br/secretarias/negro-indiomeio-ambiente-e-minorias/>. Acesso em: 26 ago. 2014.

Partido Verde. Programa partidário. Disponível em: <http://pv.org.br/opartido/programa/>. Acesso em: 30 ago. 2014.

\title{
Resumo
}

Política partidária e meio ambiente: a adesão dos partidos políticos brasileiros à agenda verde

Este artigo analisa como os partidos políticos brasileiros incorporam temas ambientais em seus programas partidários. A metodologia consistiu no monitoramento dos websites dos partidos, com um mapeamento das estratégias utilizadas no que se refere à adesão das legendas à agenda socioambiental. O levantamento foi realizado no período de agosto a setembro de 2014, durante a campanha eleitoral. Dos 32 partidos registrados na Justiça Eleitoral, 20 incorporam temáticas ecológicas em seus websites $(62,5 \%)$, por meio de quatro principais estratégias: inclusão do tema no programa partidário, criação de núcleo socioambiental nos websites, oferta de cursos online de educação ambiental e divulgação de noticiário ecológico. Identificam-se quatro perfis partidários de governança ecológica: preservacionistas, desenvolvimentistas, críticos ao capitalismo e ecologistas sistêmicos. Em todos os perfis, o Estado exerce um papel central como ator das políticas ambientais propostas pelos partidos. A ampla adesão partidária aos temas ecológicos mostra que a agenda verde se tornou uma questão política estabelecida e um tema transpartidário, além da divisão esquerda $\mathrm{x}$ direita.

Palavras-chave: meio ambiente e política; partidos políticos e ambiente; política partidária e meio ambiente; programas partidários; perfis partidários de governança ambiental

\begin{abstract}
Political parties and environment: how Brazilian political parties incorporate environmental issues in their party programs

This article examines how political parties incorporate environmental issues in their party programs. The methodology consisted in monitoring the websites of political parties, with a mapping of the strategies used in relation to the environmental agenda. The survey was conducted in the period August-September 2014, during the election campaign. Of the 32 parties registered with the Electoral Court, 20 incorporate environmental themes into their websites $(62.5 \%)$, through four main strategies: inclusion of the issue in the party program, creating the websites nucleus to environmental issue, offering online courses in environmental education and dissemination of environmental news. Four profiles of environmental governance are identified: preservationists, developmental, critical of capitalism and systemic ecologists. In all profiles, the state plays a central role as an actor of environmental policies proposed by parties. The wide partisan adherence to ecological issues shows that the green agenda has become established and a political issue transparty theme, beyond the left $x$ right divide.
\end{abstract}

Keywords: environment and politics; political parties and the environment; party politics and the environment; party programs; supporters of environmental governance profiles 


\section{Resumen}

La política partidista y el medioambiente: la adhesión de los partidos políticos brasileños a la agenda verde

Este artículo analiza cómo los partidos políticos brasileños incorporan temas ambientales en sus programas partidistas. La metodología consistió en el seguimiento de los sitios web de los partidos, con un mapeo de las estrategias utilizadas en relación con la adhesión de los partidos a la agenda ambiental. La encuesta se realizó entre agosto y septiembre de 2014, durante la campaña electoral. De los 32 partidos registrados ante la Justicia Electoral, 20 incorporaron las cuestiones ecológicas en sus sitios web $(62,5 \%)$, a través de cuatro estrategias principales: la inclusión del tema en el programa del partido, creando un núcleo socio-ambiental en los sitios web, que ofrece cursos en línea en la educación ambiental y la difusión de noticias ambientales. Se identifican cuatro perfiles partidarios de la gobernanza ecológica: preservacionistas, de desarrollo, críticos del capitalismo y ecologistas sistémicos. En todos los perfiles, el Estado tiene un papel central como actor de las políticas ambientales propuestas por los partidos. La gran adhesión partidista a las cuestiones ecológicas demuestra que la agenda verde se ha convertido en un tema transpartidário y una cuestión política establecida, más allá de la división izquierda $\mathrm{x}$ derecha.

Palabras clave: medio ambiente y política; los partidos políticos y el medioambiente; la política partidista y el medioambiente; programas de los partidos; perfiles partidarios de gobernanza ambiental.

\section{Résumé}

Politique partisane et de l'environnement : I'adhésion des partis politiques brésiliens à l'agenda vert

Dans cet article, nous analysons la façon dont les partis politiques brésiliens intègrent les questions environnementales dans leurs programmes. La méthodologie a consisté à suivre de près les sites internet des partis, à réaliser une cartographie des stratégies utilisées dans le cadre de I'adhésion des partis à l'ordre du jour environnemental. La collecte de données a été réalisée d'août à septembre 2014, pendant la campagne électorale. Sur les 32 partis inscrits auprès de la Justice électorale, 20 incorporent des thématiques écologiques sur leurs sites internet (62,5\%), au moyen de quatre stratégies principales : I'inclusion du thème dans le programme du parti, la création d'un centre environnemental sur les sites Internet, la mise à disposition en ligne de cours d'éducation environnementale et la diffusion de bulletin d'informations sur l'environnement. On identifie quatre profils partisans de gouvernance écologique : les préservationnistes, les développementistes, les critiques envers le capitalisme et les écologistes systémiques. Dans chacun de ces profils, I'État exerce un rôle central en tant qu'auteur des politiques environnementales proposées par les partis. Le large soutien des partis aux thèmes écologiques montre que I'agenda vert est devenu une question politique établie et un thème trans-partis, au-delà de la division gauche-droite.

Mots-clés : I'environnement et la politique ; les partis politiques et I'environnement ; la politique partisane et de I'environnement; les programmes des partis; les profils de gouvernance environnementale. 